\title{
Study on the Mechanism and Kinetics of Manganese Release from Waste Manganese Ore Waste Rock Under Rainfall Leaching
}

\section{Xin Wang}

Hunan University of Science and Technology

Bozhi Ren ( $\sim$ BozhiRen@126.com)

Hunan University of Science and Technology https://orcid.org/0000-0002-9797-7314

\section{Yingying Zhou}

Hunan University of Science and Technology

Xiyang Shi

Hunan University of Science and Technology

\section{Research Article}

Keywords: Manganese ore waste, Release law, Kinetic characteristics,Rainfall leaching

Posted Date: May 11th, 2021

DOl: https://doi.org/10.21203/rs.3.rs-414722/v1

License: (c) This work is licensed under a Creative Commons Attribution 4.0 International License. Read Full License

Version of Record: A version of this preprint was published at Environmental Science and Pollution Research on August 23rd, 2021. See the published version at https://doi.org/10.1007/s11356-021-16081W. 


\title{
Study on the mechanism and kinetics of manganese release from
}

\section{waste manganese ore waste rock under rainfall leaching}

\author{
Xin Wang ${ }^{1}$, Bozhi Ren ${ }^{1,2, *}$, Yingying Zhou ${ }^{1}$, Xiyang Shi ${ }^{1}$
}

${ }^{1}$ School of Civil Engineering, Hunan University of Science and Technology, Xiangtan,411110,Hunan,P.R.China;E-Mails:wx13348779695@163.com(X.W.);bozhiren@ 163.com(B.R.);438640474@qq.com(Y.Z.);2329201951@qq.com(X.S.)

${ }^{2}$ Hunan Provincial Key Laboratory of Shale Gas Resource Exploitation, Xiangtan,411110,Hunan,P.R. China

* Corresponding author: bozhiren@126.com (B.R.); Tel. +86-13107126636; Fax:

$+86-0731-58290182$

\section{Abstract}

Manganese released from manganese ore wastes under leaching poses a serious threat to the local ecosystem and human health. The mechanism and dynamic characteristics of manganese release under the leaching of manganese ore waste rock are studied based on static and dynamic experiment. The concentration of manganese in the leaching solution under the disturbance state is twice as much as that in the static state; the manganese release from the waste rock increases with the increase of the solid-liquid ratio, and the manganese release is $922.35 \mathrm{mg} / \mathrm{l}$ when the solid-liquid ratio is 1:5; when the particle size of waste rock is greater than 80 mesh, the precipitation amount of manganese is the largest, and the precipitation concentration is $491.3 \mathrm{mg} / \mathrm{l}$; at $\mathrm{pH}=7$, rainfall intensity is 80 With the increase of leaching time, the amount of manganese released rapidly decreased and gradually reached equilibrium; the cumulative release of manganese increased with the increase of rainfall duration. In the dynamic leaching process, the change of $\mathrm{pH}$ and $\mathrm{EC}$ of leachate has nothing to do with the initial $\mathrm{pH}$ of leachate, but has a close relationship with the hydrolysis of minerals in waste; through the fitting results of kinetic model, it is found that the double constant equation model can better fit the kinetic process of release process. The purpose of this study is to provide a scientific basis for the assessment and control of manganese pollution in soil and groundwater in manganese mining area.

Keywords: Manganese ore waste; Release law; Kinetic characteristics;Rainfall leaching 


\section{Introduction}

Manganese (Mn) is a kind of global pollution substance (Bozhi,R et al.2015; Li,Y et al.2018;

Bozhi, R et al.2014), with biodegradability, strong accumulation potential and high toxicity(Ning, $\mathrm{P}$ et al.2018; Yingying, $\mathrm{Z}$ et al.2017; Ning, L et al.2017). With the development of economy, the utilization of manganese resources is increasing, and many waste rocks are produced in the process of continuous mining in manganese ore area, resulting in the formation of rock storage yard(Bozhi, R et al.2014; Jianbing, $\mathrm{W}$ et al.2014).Under the effect of rainfall leaching, manganese leaching liquid from waste rock storage yard migrates with rainfall infiltration and surface runoff, and enters into the soil, underground and surface water of mining area, resulting in manganese compound pollution of soil and regional water environment in manganese mining area is becoming more and more serious, causing great harm to human health, which is a key problem to be solved urgently in national economic and social development(Saijun, Z et al.2019; Hai, L et al.2014; Bozhi, R et al.2017).

Domestic and foreign studies focused on the release of heavy metals from soil, sludge, dust and other solid media by simulated rainfall, and the influence of a series of factors on waste leaching mode(Zhang, Y et al.2018; Zhou, Y et al.2019; Xuejun, G et al.2014; Zhou, S et al.2017; Siyu, $\mathrm{Z}$ et al.2018; Zhangxiong, $\mathrm{H}$ et al.2017; Emilia, F.O et al.2017; Kukurugya, $\mathrm{F}$ et al.2017; Bing, L et al.2016; Herndon, E.M et al.2018; Sun, Z et al.2018; Zhang, Y et al.2019). For example, the leaching law of heavy metals in Taolin Lead-Zinc Tailing area in Hunan under simulated acid rain leaching ( $\mathrm{Li}, \mathrm{Y}$ et al.2012), leaching characteristics and changes of antimony bearing ore leaching layer in China(Xingyun, $\mathrm{H}$ et al.2016), and Research on leaching of heavy metals from antimony tailings by microbial sulfur oxidizing bacteria have achieved good research results(Qingqing, $Z$ et al.2014). However, there are few studies on the release characteristics and cumulative leaching mechanism of manganese under continuous rainfall. In view of this situation, the aim of this study is to the leaching and release characteristics of manganese from manganese ore waste rock, explores the influence of disturbance ratio, solid-liquid ratio, particle size, rainfall intensity and rainfall $\mathrm{pH}$ on manganese release, and establishes a dynamic model of manganese. The application of this model helps understand manganese and other related characteristics of heavy metal pollution prevention 
and treatment, and more conducive to the sustainable long-term development of non-ferrous metal mining areas. Therefore, it is an important scientific basis for establishing the evaluation and control system of manganese pollution in soil and groundwater of manganese mine area to master the mechanism and dynamic characteristics of manganese release under leaching of manganese ore waste rock.

\section{Materials and methods}

\subsection{Experimental materials}

The waste rock samples were collected from the Hongqi mining area, Xiangtan City, Hunan Province. The samples collected at the site were mixed evenly and then dried in the laboratory to remove the large waste rock and biological debris, and other unrelated substances, and the waste rock samples were ground on the grinder. After air drying, the samples were graded by stainless steel screen $(20,40,60,80$ mesh respectively), and the pretreated waste rocks with different particle sizes were stored for use.

\subsection{Experimental apparatus and methods}

\subsubsection{Static leaching simulation experiment}

The static leaching experiment device uses $1000 \mathrm{ml}$ wide-mouth bottle and rotary oscillator. According to the nature of rainwater in Hunan Province, ultra pure water is used in the experiment, and $10 \% \mathrm{H}_{2} \mathrm{SO}_{4}$ and $\mathrm{HNO}_{3}$ mixture $(\mathrm{V} / \mathrm{V}: 1 / 1)$ and $10 \% \mathrm{NaOH}$ solution are used to adjust to the required $\mathrm{pH}$ value $(\mathrm{pH}=5.0)$. During the experiment, $5 \mathrm{ml}$ samples were taken from the flask after standing for $10 \mathrm{~min}$ every $24 \mathrm{~h}$. The samples were filtered through $0.45 \mu \mathrm{m}$ filter membrane, and the concentration of $\mathrm{Mn}$ was determined by flame atomic absorption spectrophotometer. The experimental period was 24 days. Parallel double samples were used in the same condition experiment.

(1) Effect of different disturbance ratio on Mn release from waste rock: $10 \mathrm{~g}$ waste rock with grading mesh more than 80 mesh, add $1000 \mathrm{ml}$ wide mouth bottle, and add $200 \mathrm{ml}(\mathrm{pH}=5.0)$ mixed leaching solution. A 24-day static leaching experiment was carried out by placing the wild-mouth bottle with static condition on the experimental platform and the flask with disturbance condition on a rotary oscillator (oscillation condition: $150 \mathrm{R} / \mathrm{min}$ ).

(2) Effect of different solid-liquid ratio on Mn release from waste rock: $40 \mathrm{~g}, 20 \mathrm{~g}, 10 \mathrm{~g}$ and 5 
$\mathrm{g}$ of waste rock with grading mesh number less than 80 mesh were respectively added into 1000 $\mathrm{ml}$ wide mouth bottle, and $200 \mathrm{ml}(\mathrm{pH}=5.0)$ mixed leaching solution (solid-liquid ratio: 1:5, 1:10, 1:20, 1:40). All the flasks were placed on the rotary shaker (oscillation condition: $150 \mathrm{R} / \mathrm{min}$ ).

(3) Effects of different particle sizes on Mn release from waste rock: $10 \mathrm{~g}$ of waste rock with 20-40 mesh, 40-60 mesh, 60-80 mesh and > 80 mesh waste rock were respectively weighed and added into a $1000 \mathrm{ml}$ wide mouth bottle, and $200 \mathrm{ml}(\mathrm{pH}=5.0)$ mixed leaching solution was added. All the flasks were placed on the rotary shaker (oscillation condition: $150 \mathrm{R} / \mathrm{min}$ ).

\subsubsection{Dynamic leaching simulation experiment}

A self-made column was used to simulate the dynamic leaching process. The experimental device includes water storage beaker, peristaltic pump, self-made leaching column, etc., as shown in Fig. 1. The water storage beaker is mainly used to store the leaching solution required by different leaching conditions every day as the inlet of the peristaltic pump, the peristaltic pump is the simulation power of the dynamic leaching experiment rainwater, controlling the intensity and rainfall of the simulated rainwater, the self-made leaching column is the main place for leaching reaction, and the inner diameter of the hollow cylinder is $5 \mathrm{~cm}$, the lower end is sealed and equipped with a water collection device.

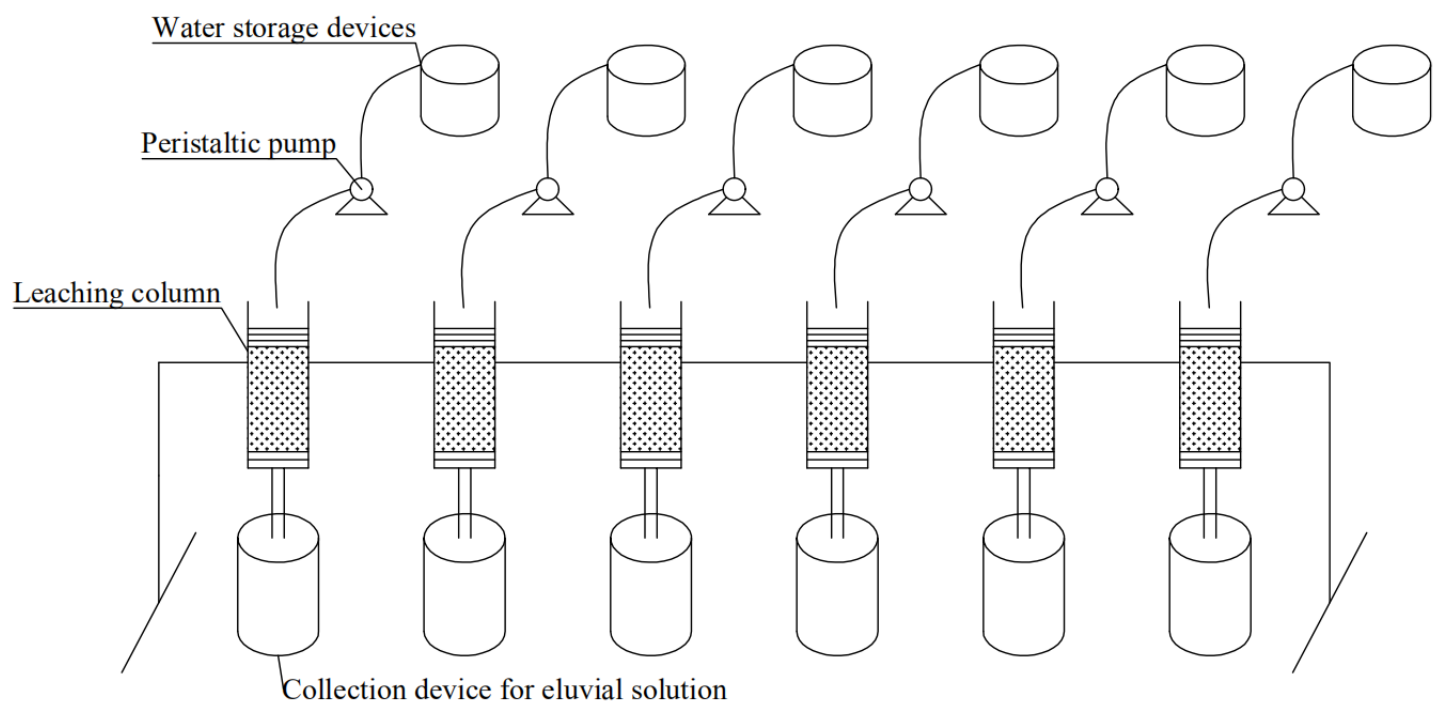

Fig. 1 dynamic leaching experimental device

The annual $\mathrm{pH}$ of acid rain in Hunan Province is maintained at $4.06 \sim 6.36$, with an average of 4.98, the acid rain control area of the sulfuric acid type. Therefore, the $\mathrm{pH}$ value of simulated rainwater is adjusted by the mixture of $\mathrm{H}_{2} \mathrm{SO}_{4}$ and $\mathrm{HNO}_{3}(\mathrm{~V} / \mathrm{V}: 3 / 1)$ and $\mathrm{NaOH}$ solution. 
According to the rainfall statistics of Xiangtan Meteorological Bureau in recent ten years (2006-2015), the runoff loss in rainfall (about 30\%) was considered in the experiment, and the simulated rainfall under different conditions was formulated as follows:

The average annual rainfall in recent ten years is $1383.2 \mathrm{~mm}$; after deducting the influence of surface runoff (30\%), the monthly average rainfall from January to December is: $43.4 \mathrm{~mm}, 42.9$ mm, $98.0 \mathrm{~mm}, 86.0 \mathrm{~mm}, 141.4 \mathrm{~mm}, 168.9 \mathrm{~mm}, 98.7 \mathrm{~mm}, 77.6 \mathrm{~mm}, 63.6 \mathrm{~mm}, 27.5 \mathrm{~mm}, 78.6 \mathrm{~mm}$, $41.8 \mathrm{~mm}$; the inner diameter of the self-made leaching column is $5 \mathrm{~cm}$. The results showed that the average monthly leaching amount was $115 \mathrm{ml}$, and that in rainy season (from May to July) was $268 \mathrm{ml}$. From the bottom to the top, they are $2 \sim 3$ layers of filter paper, 1 layer of non-woven fabric, $2 \sim$ $3 \mathrm{~cm}$ high fine quartz sand, waste rock, 1 layer of non-woven fabric, $2 \sim 3 \mathrm{~cm}$ fine quartz sand. Among them, the bottom quartz sand acts as a supporting layer, the bottom non-woven fabric and filter paper is used to prevent the loss of waste rock in the leaching process, and the top quartz sand plays the role of uniform water distribution. 250g manganese ore waste rock was respectively weighed and filled into the waste rock layer in the leaching column and vibrated gently to make it dense. Then $500 \mathrm{ml}$ ultra pure water was slowly added and naturally drained for $24 \mathrm{~h}$.In the experiment, the volume of filtrate was determined by $1 \sim 2 \mathrm{ml}$ evaporation per day.The leaching simulated rainwater with $\mathrm{pH}$ of 3.0, 5.0, 7.0 and 9.0 was prepared by the above preparation solution was collected at the bottom of the leaching column and the manganese concentration was determined. After each leaching, it was placed naturally until the next day. The specific experimental steps are as follows:

(1) Effects of different rainfall intensities on Mn release from manganese ore waste rock: The simulated rain water with $\mathrm{pH}=5.0$ was prepared by adding $268 \mathrm{ml}$ leaching solution to simulate the rainfall in rainy season every day. The leaching cycle was 20 days. The influent flow was controlled to simulate three levels of rainfall intensity: $80 \mathrm{ml} / \mathrm{h}, 200 \mathrm{ml} / \mathrm{h}$ and $400 \mathrm{ml} / \mathrm{h}$.

(2) Effect of different rainfall $\mathrm{pH}$ on $\mathrm{Mn}$ release from manganese ore waste rock: The method, and $115 \mathrm{ml}$ leaching solution of simulated monthly average rainfall was added every day. The leaching cycle was 20 days. The influent flow was controlled to $400 \mathrm{ml} / \mathrm{h}$. 
(3) The effect of different rainfall duration on Mn release from manganese ore waste rock:

138 The simulated rainwater with $\mathrm{pH}=5.0$ was prepared by the preparation method mentioned above, 139 and the influent flow was controlled to 400 by peristaltic pump The leaching cycle was 12 days, 140 and the leaching time was 12 days.

\section{$141 \quad 2.3$ Analysis methods}

142 Manganese content was determined by the nitric acid perchloric acid, hydrofluoric acid system, 143 high concentration was determined by flame atomic absorption spectrometry, and low 144 concentration was determined by atomic fluorescence spectrometry. The crystal structure of waste 145 rock was determined by $\mathrm{X}$-ray diffraction $(\mathrm{XRD}), \mathrm{pH}$ value was determined by soil $\mathrm{pH}$ method 146 NY / T 1377-2007. The total conductivity of leachate was measured by ddbj-350 conductivity 147 meter.

\section{$148 \quad 3$ Results and discussions}

\section{$149 \quad 3.1$ Effect of disturbance ratio on manganese release from manganese ore waste}

150 It can be seen from Fig. 2 that in the static leaching experiment, the manganese concentration 151 in the leaching solution increases with the increase of time and then tends to balance gradually and 152 keeps fluctuating in a small range. Under the oscillation condition, Mn has a certain leaching concentration on the first day of leaching, and then increases slowly in the next few days (about

154 the first 6 days). After that, the manganese concentration in the leaching solution rapidly increases to the maximum value and reaches the equilibrium concentration around the 15 th day. The concentration in the leaching solution fluctuates in a small range. Under the static condition, the concentration of manganese in the leaching solution fluctuates with time after it has the basic leaching concentration on the first day. It can be seen that the concentration of manganese in the leaching solution in the oscillation state is obviously higher than that in the static state, and it can reach about twice the leaching concentration under the static state under the experimental conditions.

On the first day of the experiment, the acid $(\mathrm{pH}=5.0)$ in the solution neutralizes with the 163 alkaline substance in the waste rock, and manganese in the waste rock will be released quickly 164 into the leaching solution, and then the solution will be in alkaline state (pH is between 6-8) under the action of alkaline minerals. The disturbance state will increase the concentration gradient of 
hydraulic shear effect and friction collision between particles when the solution is agitated, The micro balance formed on the surface of manganese ore waste rock particles will be destroyed under the synergistic effect of hydraulic shear effect and friction collision, causing the release and migration of manganese from waste rock to solution. In the static state, manganese is mainly released by acid-base neutralization of waste rock in the early stage, and then further diffusion of manganese is hindered at the surface equilibrium, so manganese is easier to be precipitated under the oscillating condition than under the standing condition.

174

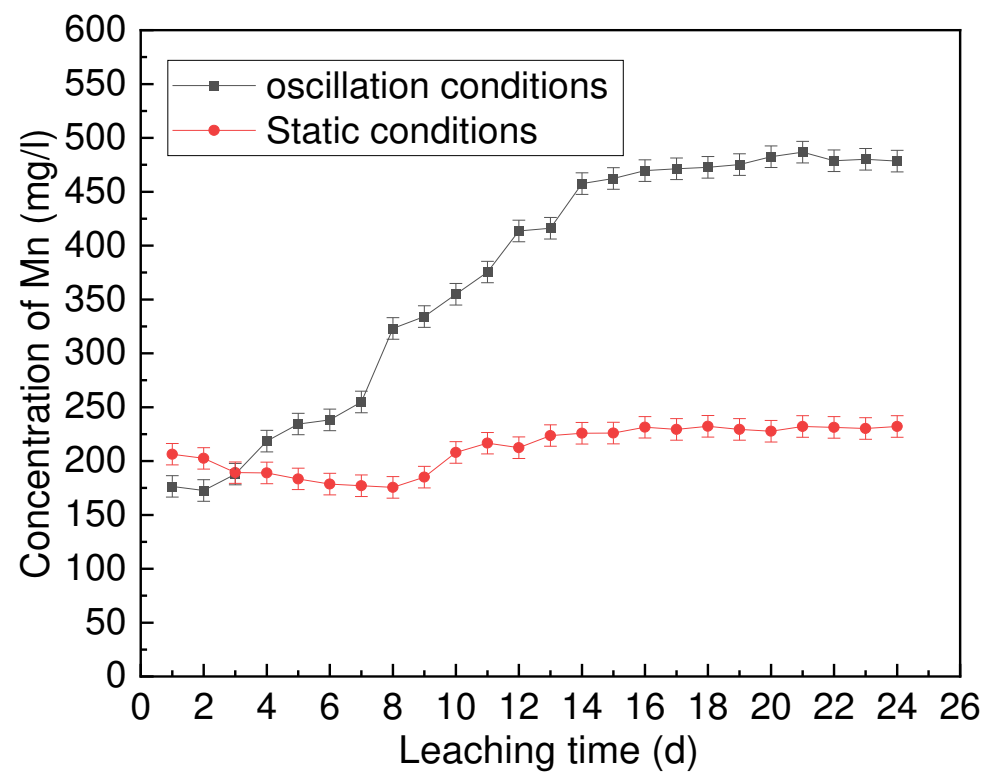

Fig. 2 Effect of disturbance ratio on Mn leaching concentration

\subsection{Effect of different particle size and solid-liquid ratio on manganese release from manganese ore waste}

According to Fig. 3, the effect of manganese is small when the particle size (20-80 mesh) is large. The leaching concentration and dissolution rate of manganese in the leaching solution with three different particle sizes remain basically unchanged, and are less affected by the particle size. When the particle size is greater than 80 mesh, the dissolution release rate and leaching concentration of $\mathrm{Mn}$ are significantly higher than those in the other three conditions.

When the particle size is small, the manganese concentration in the same solid mass is slightly higher than that in the large particle size, which will increase the base number of manganese release. In addition, the smaller the particle size is, the larger the specific surface area of the same mass of waste rock is, the larger the total contact area of solid and liquid will be in the experiment.

The larger the leaching area of solid surface obtained by unit liquid is, it is conducive to the 
dissolution and release of manganese. The larger the size of manganese ore, the smaller the possibility of release of manganese from waste rock. In the natural mine environment, microbial action will accelerate the change of instability, and the surface organic matter may form a layer of weathering resistant surface zone, which will hinder the further change of particle size. It is shown in Fig. 4 that the leaching concentration and dissolution rate of manganese have little change when the solid-liquid ratio is $1: 20,1: 10$ and $1: 5$, while the leaching concentration of manganese is obviously lower than the other three conditions when the solid-liquid ratio is 1:40, and it will reach equilibrium soon in the early stage of the experiment. The reason may be that when the solid-liquid ratio is small to a certain extent, the effect of manganese concentration gradient plays a leading role in the dissolution and release, and the basic concentration of manganese in the waste rock with small solid-liquid ratio is lower than that of large solid-liquid ratio, so the concentration at the solid-liquid ratio of 1:40 is obviously lower than that of other conditions, and in the higher solid-liquid ratio, other factors play a leading role, and are more affected by the solid-liquid ratio Small.

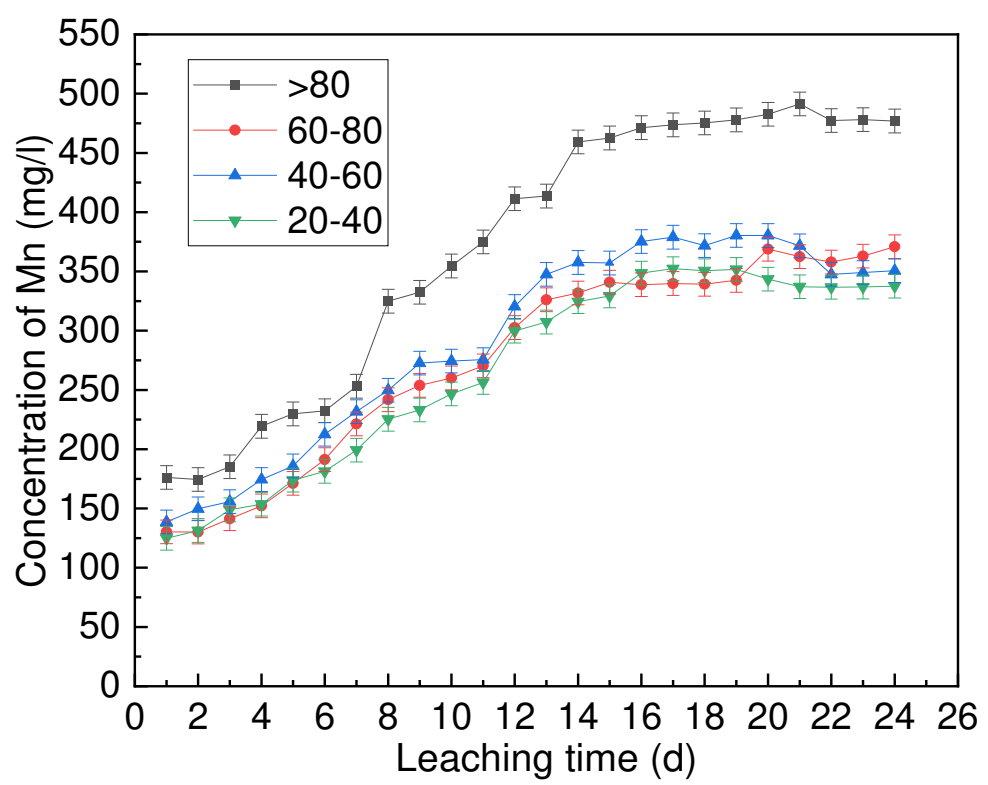




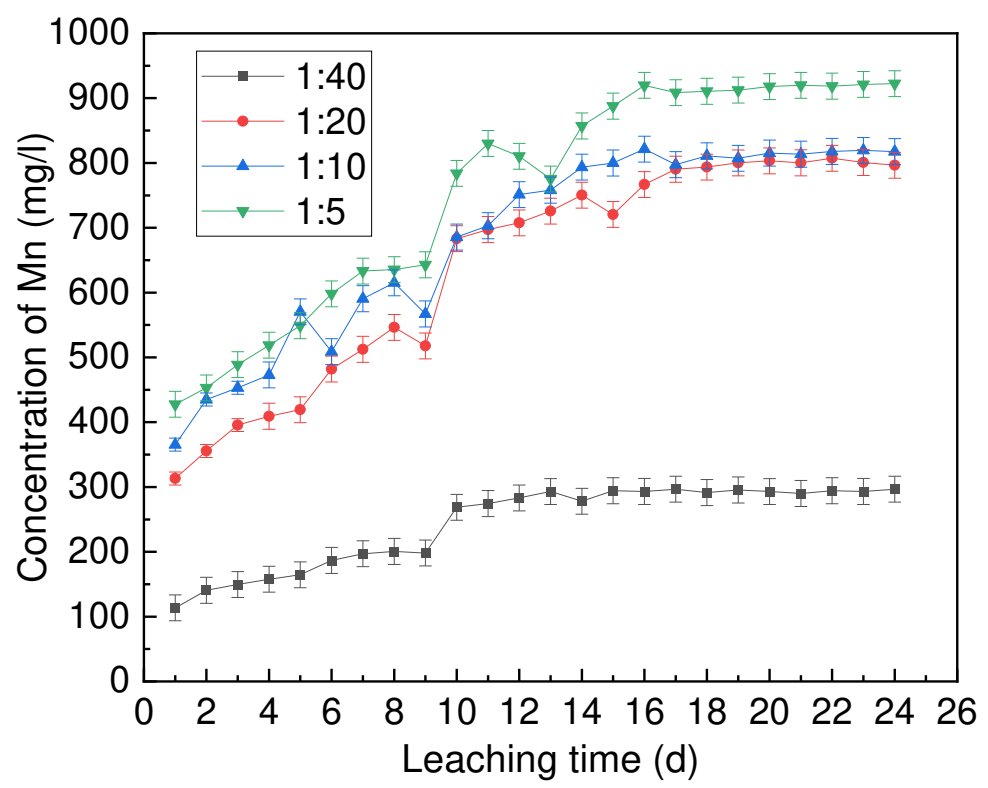

Fig. 4 Effect of solid-liquid ratio on Mn leaching concentration

\subsection{Effect of different rainfall intensity on manganese release from waste rock}

It can be seen from Fig. 5 that the concentration of manganese is extremely high on the first day of leaching, and then rapidly decreases. The release concentration reaches the minimum value on the seventh day of leaching, and the manganese content after leaching is extremely low. Under different rainfall intensities, the effect of different rainfall intensities on manganese is small, which is mainly reflected in the dissolution concentration and concentration reduction rate of manganese in the first two days. In the early stage of small rainfall intensity $(80 \mathrm{ml} / \mathrm{h})$, manganese is released from waste rock. There is little difference between the rainfall intensity of $200 \mathrm{ml} / \mathrm{h}$ and $400 \mathrm{ml} /$ $\mathrm{h}$, but the release concentration of $200 \mathrm{ml} / \mathrm{h}$ is slightly greater than that of $400 \mathrm{~L} / \mathrm{h}$. According to the observation in the experimental process, due to the limited infiltration capacity of the dense leaching column, different surface rainfall ponding will be formed at different rainfall intensities. The basic situation is: There was no ponding on the surface of $80 \mathrm{ml} / \mathrm{h}$ leaching column, a very shallow ponding on the surface of $200 \mathrm{ml} / \mathrm{h}$ leaching column, and a certain height of water column on the surface of $400 \mathrm{ml} / \mathrm{h}$ leaching column (the maximum is about $5 \sim 8 \mathrm{~cm}$ ). Under the experimental conditions, when the surface ponding is formed, the experimental conditions will transition from leaching to soaking stage of slow seepage, at which time the erosion and shear effect of rainwater on the surface ore decrease. In the case of no ponding, the accumulated voids of ores are significantly larger than those of water bearing ores, and the oxygen in the outside air 
will be deeper in the leaching column than in other conditions, which will promote the oxidation of sulfide and the release of manganese. These are the reasons that lead to low rainfall intensity and high manganese release concentration.

Under different rainfall intensities, the $\mathrm{pH}$ value of leaching solution is between 6.5 and 8.0, which is basically neutral and slightly alkaline (Fig. 6a). Alkaline substances in minerals react with acid in rainwater to form alkaline leaching solution.

The conductivity of leaching solution reflects the difficulty of charge flow in the solution, that is, the comprehensive embodiment of the number of ions and charges in the solution. In the experimental cycle, the curve of conductivity with time under different intensities is shown in Fig. 6b. It can be seen from the figure that the three rainfall intensities $(80 \mathrm{ml} / \mathrm{h}, 200 \mathrm{ml} / \mathrm{h}$ and 400 $\mathrm{ml} / \mathrm{h}$ ) in the experiment decreased from 3.10 MS / cm, 2.84 MS / cm and 2.82 MS / cm to 1.168 MS / cm, 1.165 MS / cm and 0.742 MS / cm, respectively. In the first five days, the three rainfall intensities maintained a high conductivity, and then decreased rapidly, and the conductivity remained basically unchanged on the 17 th day. In the early stage of the experiment, when acid rain reacts with alkaline minerals on the surface of manganese ore waste rock violently during the leaching process, $\mathrm{Na}^{+}, \mathrm{K}^{+}, \mathrm{Ca}^{2+}, \mathrm{Mg}^{2+}$ in the waste rock are dissolved and released into the pore water. Therefore, the conductivity of the leachate in the initial stage is large and the dissolution rate is high in the previous days. With the increase of leaching time, acid-base neutralization and promoting the dissolution of alkaline substances in the acid-base reaction process of acid rain water with alkaline minerals increase the $\mathrm{pH}$ value of pore water in the leaching column (Fig. 6a). The upper mineral reacts with acid, and the leachable ion material decreases with the increase of leaching time, while in the deep layer of the column, the alkaline environment is formed gradually due to the influence of alkaline minerals, which promotes the adsorption and precipitation of various ions, reduces the total amount of ions in the leachate, and finally reaches the equilibrium state. The daily conductivity of leachate keeps a small range of change, and continues to extend with time It's going to get lower and lower. 


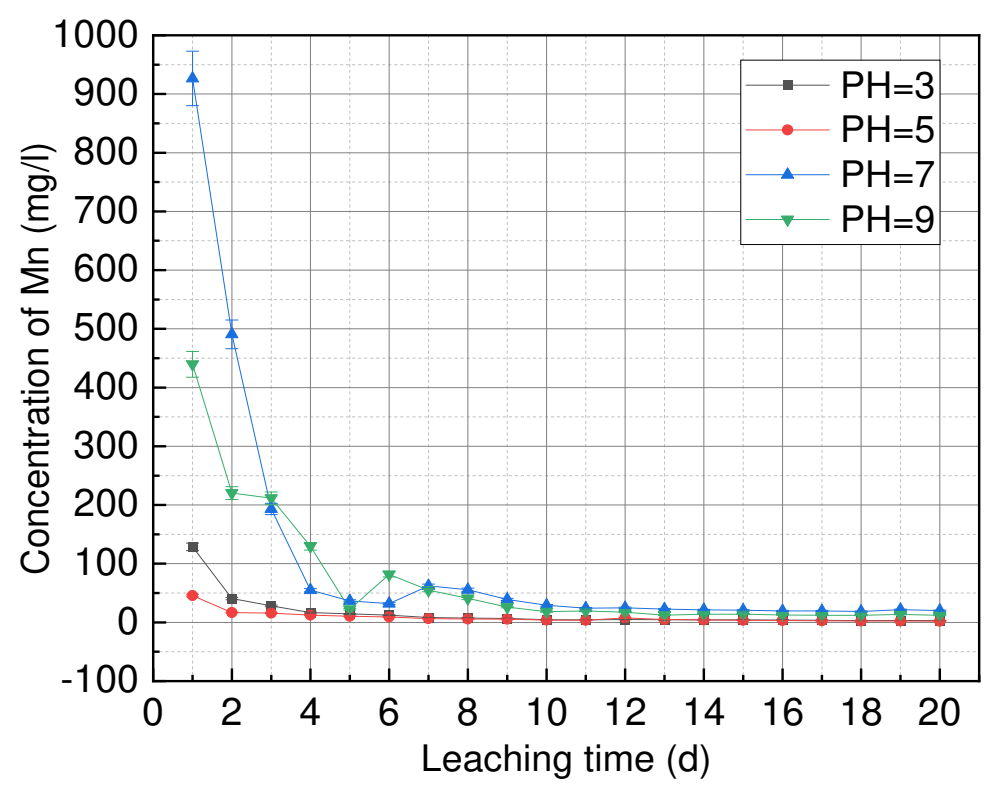

Fig. $5 \mathrm{Mn}$ precipitation under different rainfall intensities
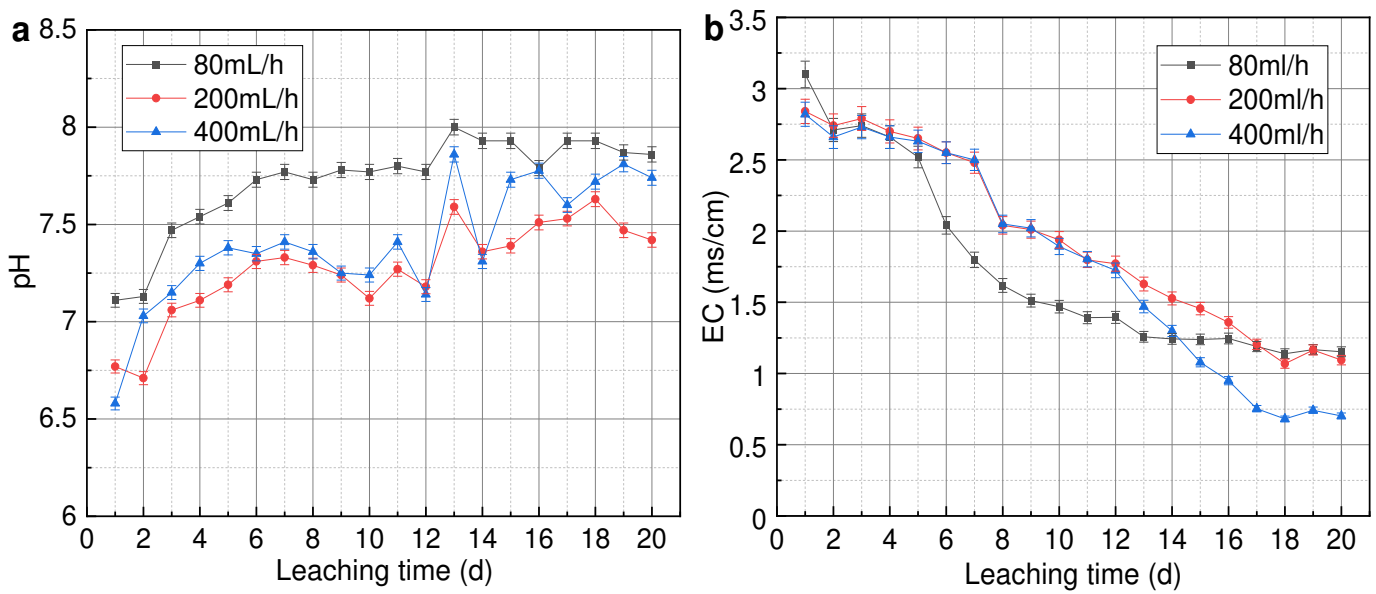

Fig. 6 Effects of different rainfall intensities: a) pH value of leachate; b) EC Value of leachate

\subsection{Manganese release characteristics of manganese ore waste rock under different rainwater $\mathrm{pH}$}

The release of $\mathrm{Mn}$ under different rainfall $\mathrm{pH}$ is shown in Fig. 7. The concentration of manganese is extremely high on the first day of leaching, and then rapidly decreases. The release concentration reaches the minimum value on the 12th day of leaching, and the manganese content after leaching is extremely low. Under different rainfall acidity, the leaching concentration of manganese in leachate was the highest on the first day, and decreased rapidly in the first four days, and then gradually decreased to the lowest value every day. In the experiment, the dissolution concentration of manganese in four kinds of rain water with different $\mathrm{pH}$ values is $\mathrm{pH}=7.0>\mathrm{pH}$ $=9.0>\mathrm{pH}=3.0>\mathrm{pH}=5.0$, which shows that the dissolution concentration of manganese increases with the decrease of $\mathrm{pH}$ value in acid rain water, and increases with the decrease of $\mathrm{pH}$ 
value in alkaline rain water, but the dissolution concentration of Mn under alkaline condition is higher than that under acid condition. Under acidic conditions, manganese bearing minerals are easy to dissolve, resulting in a high concentration in the leachate. With the neutralization of alkaline minerals in the reaction, the effluent leachate will become alkaline. Under the alkaline condition, the experiments show that when the $\mathrm{pH}$ value of manganese ion solution is higher than 8.0, obvious precipitation will appear in the solution. In this experiment, manganese is easier to be released from minerals under alkaline conditions, but when the alkalinity is strong, it is easy to form precipitation, which makes the content of manganese ions in pore water decrease, and the alkaline substance dissolution rate of manganese after precipitation is relatively slow, so the concentration of $\mathrm{Mn}$ ion in the solution is higher when the $\mathrm{pH}$ value of simulated alkaline rainwater is smaller.

Under different rainfall $\mathrm{pH}$ conditions, whether the initial rainwater is alkaline or acidic, the $\mathrm{pH}$ value in the final leachate is between 6.5 and 8.0 (Fig. 8a). The existence of minerals in manganese ore waste rock has a good buffer effect. The neutralization of alkaline minerals in minerals and the oxidation of sulfide minerals play a very good role as a buffer, so that the $\mathrm{pH}$ of rainwater is between 3-9, and the $\mathrm{pH}$ of effluent is between 6.5-8.0.

In the experimental cycle, the curve of conductivity with time in the leachate under different rainwater $\mathrm{pH}$ conditions is shown in Fig. 8b. The $\mathrm{pH}$ of four kinds of rainfall in the experiment (pH: 3, 5, 7, 9) decreased from the initial 3.03 MS / cm, 2.77 MS / cm, 5.25 MS / cm, $3.24 \mathrm{MS} / \mathrm{cm}$ to $1.725 \mathrm{MS} / \mathrm{cm}, 1.742 \mathrm{MS} / \mathrm{cm}, 1.288 \mathrm{MS} / \mathrm{cm}$ and $1.231 \mathrm{MS} / \mathrm{cm}$, respectively. In acidic condition, the conductivity of leachate maintained high in the first seven days, then decreased slowly, while in alkaline condition, the conductivity decreased rapidly from the first day. The conductivity of Leachate under acidic condition is significantly higher than that under alkaline condition, which may react with acid and alkaline minerals in rainwater violently and release various ions of alkaline minerals. However, ions are not easy to release under alkaline conditions. Moreover, iron and aluminum can adsorb and precipitate ions in pore water under alkaline conditions, which will also reduce the total number of ions in leachate. 


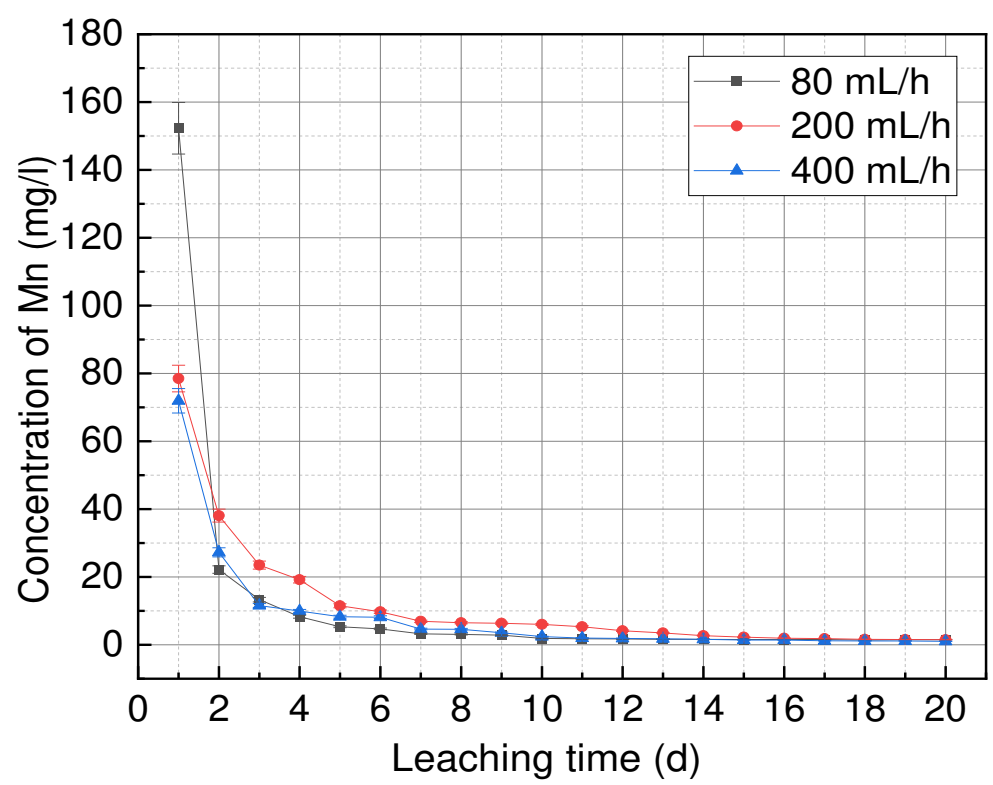

Fig. 7 precipitation of $\mathrm{Mn}$ under different rainfall $\mathrm{pH}$
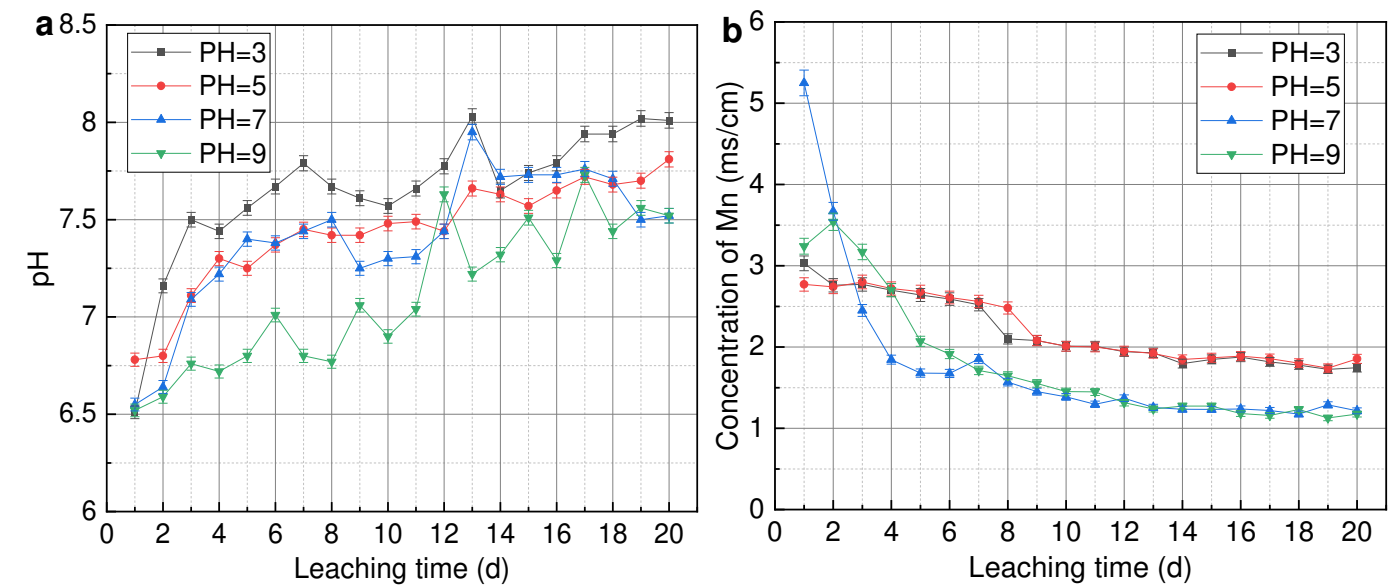

Fig. 8 Effect of different rainfall $\mathrm{pH}$ values: a) $\mathrm{pH}$ value of leachate; b) EC Value of leachate

In order to better understand the crystal structure and phase composition changes of manganese ore waste rock under the action of rainwater, X-ray diffraction (XRD) was used to test and analyze the waste rock with $\mathrm{pH}=3, \mathrm{pH}=5$ and $\mathrm{pH}=9$ after leaching experiment (as shown in Fig. 9). The peak values of basic minerals such as quartz and gypsum decrease obviously under the condition of acid leaching $(\mathrm{pH}=3.0$ and 5.0), which is due to the reaction of acid and alkaline minerals in simulated acid rain water, which leads to the mineral dissolution and loss. The dissolution of alkaline minerals makes the $\mathrm{pH}$ value of leachate increase gradually and the drainage is alkaline. At $\mathrm{pH}=9.0$, the peak value of each mineral increases obviously, which may be related to the reactive deposition of materials under alkaline conditions. 


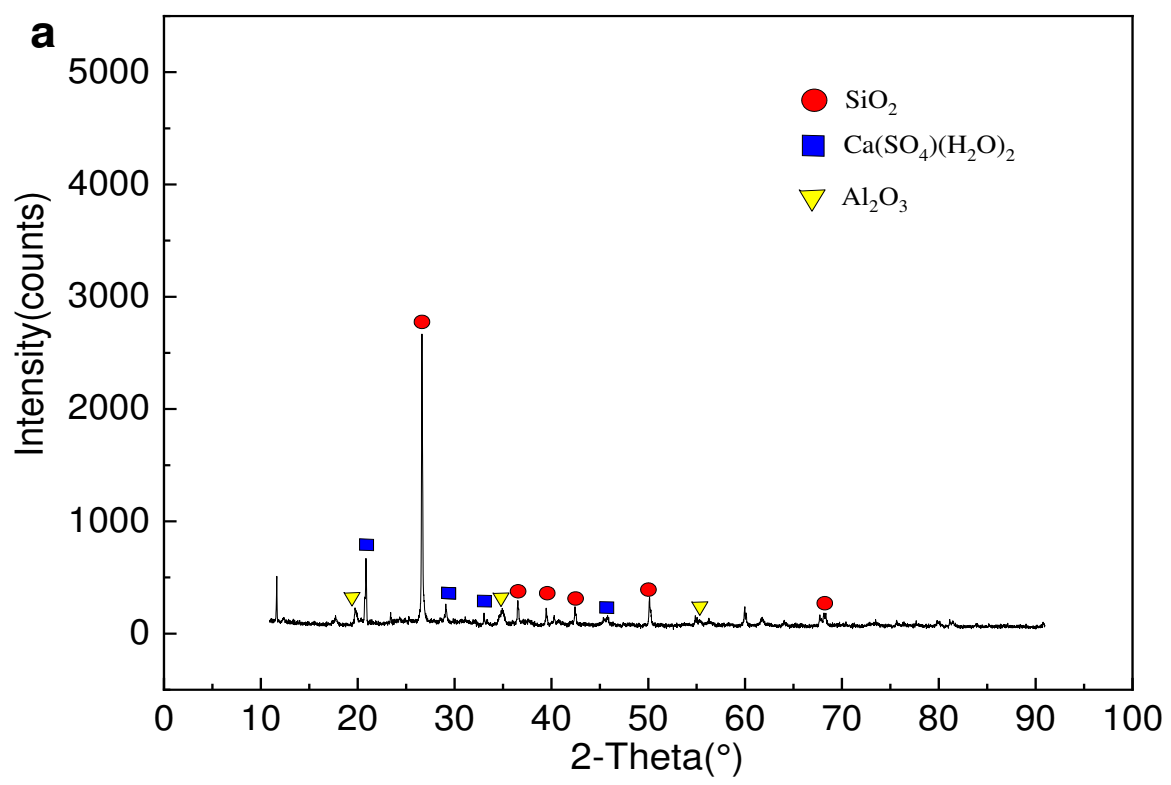

305

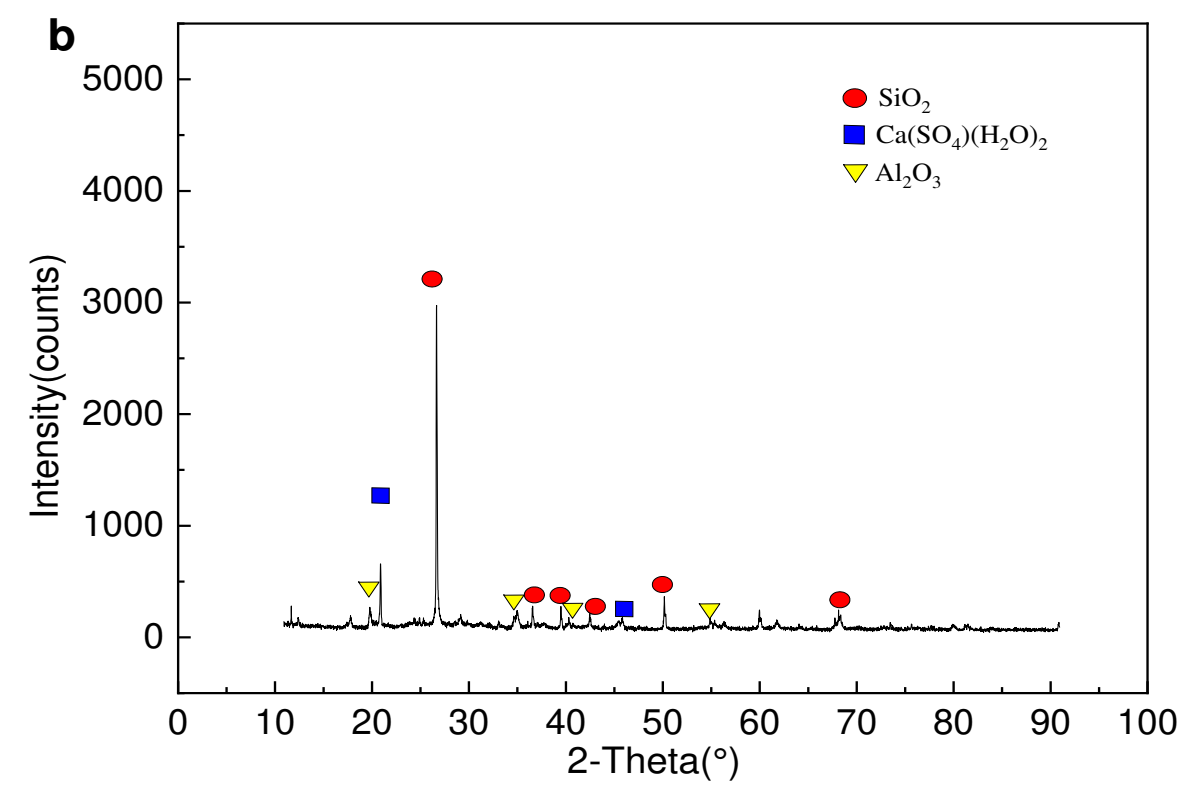




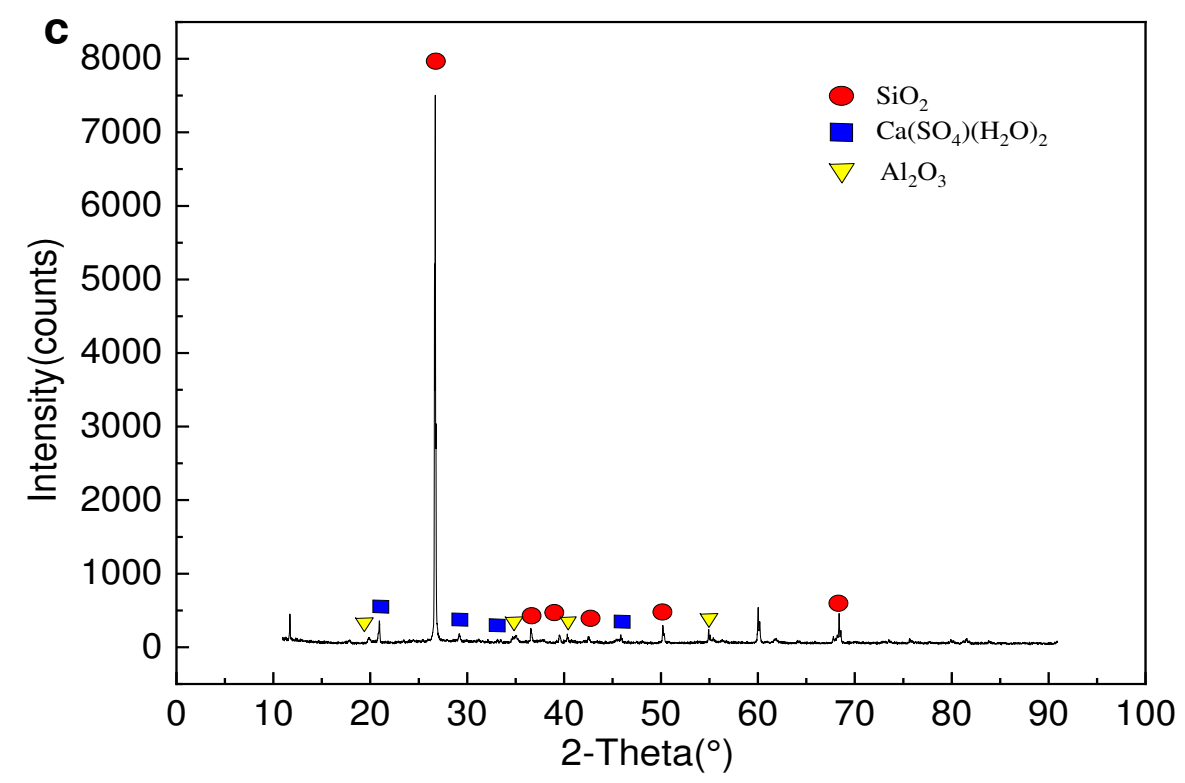

Fig. 9 X-ray diffraction pattern of manganese ore waste after leaching experiment: a) $\mathrm{pH}=3, \mathrm{~b}$ ) $\mathrm{pH}=5.0$, c) $\mathrm{pH}=$

9.0

The XRD analysis shows that there are a lot of gangue alkaline minerals mainly quartz in manganese ore waste. When the simulated rainwater passes through the surface of waste rock, the acid substance will react with the alkaline mineral of waste rock, consume $\mathrm{H}^{+}$in the aqueous solution, and increase the $\mathrm{pH}$ of the waste rock pore water, making the leaching liquid neutral or alkaline. The main basic minerals and acid reaction formulas are shown in 1-6.

$$
\begin{aligned}
& \mathrm{SiO}_{2}+4 \mathrm{H}^{+} \rightarrow \mathrm{H}_{4} \mathrm{SiO}_{4} \\
& \mathrm{CaCO}_{3}+\mathrm{SO}_{4}{ }^{2-}+2 \mathrm{H}^{+} \rightarrow \mathrm{CaSO}_{4}+\mathrm{H}_{2} \mathrm{O}+\mathrm{CO}_{2} \\
& \mathrm{CaMg}\left(\mathrm{CO}_{3}\right)_{2}+2 \mathrm{SO}_{4}{ }^{2-}+4 \mathrm{H}^{+} \rightarrow \mathrm{CaSO}_{4}+\mathrm{MgSO}_{4}+2 \mathrm{H}_{2} \mathrm{O}+2 \mathrm{CO}_{2} \\
& \mathrm{KAl}_{2}\left(\mathrm{AlSi}_{3} \mathrm{O}_{10}\right)(\mathrm{OH})_{2}+\mathrm{H}^{+}+3 / 2 \mathrm{H}_{2} \mathrm{O} \rightarrow \mathrm{K}^{+}+3 / 2 \mathrm{Al}_{2} \mathrm{Si}_{2} \mathrm{O}_{5}(\mathrm{OH})_{4} \\
& \mathrm{~K}(\mathrm{Mg}, \mathrm{Fe})_{3} \mathrm{AlSi}_{3} \mathrm{O}_{10}(\mathrm{OH})_{2}+7 \mathrm{H}^{+} \rightarrow \mathrm{K}^{+}+3\left(\mathrm{Mg}^{2+}, \mathrm{Fe}^{2+}\right)+\mathrm{Al}(\mathrm{OH})_{3}+2 \mathrm{SiO}_{2}+3 \mathrm{H}_{2} \mathrm{O} \\
& \mathrm{Na}_{0.7} \mathrm{Ca}_{0.3} \mathrm{Al}_{1.3} \mathrm{Si}_{2.7} \mathrm{O}_{8}+1.3 \mathrm{H}^{+}+1.3 \mathrm{H}_{2} \rightarrow 0.3 \mathrm{Ca}^{2+}+0.7 \mathrm{Na}+1.3 \mathrm{Al}(\mathrm{OH})_{3}+2.7 \mathrm{SiO}_{2}
\end{aligned}
$$

\subsection{Manganese release characteristics of manganese ore waste rock under different rainfall} duration

The cumulative amount of manganese precipitated during leaching is shown in Table 1 and Fig. 10. Under the same leaching speed and total amount of leaching solution, the daily leaching release amount and cumulative precipitation amount of manganese in different leaching time (rainfall duration) per day are also different. The cumulative precipitation of manganese increased 
with the increase of leaching time (rainfall duration), in which the cumulative precipitation amount of leaching time (rainfall duration) was $156.23 \mathrm{mg} / \mathrm{kg}$, when the leaching time (rainfall duration) was 3.2 hours, and $143.96 \mathrm{mg} / \mathrm{kg}$ when the leaching time (rainfall duration) was 1.6 hours. In the first five days, the daily leaching amount of manganese was significantly greater than 1.6 hours when the leaching time (rainfall duration) was 3.2 hours. It shows that the increase of rainfall duration is more conducive to the dissolution of manganese. Especially in the natural environment of alternation of dry and wet, the increase of early rainfall duration can significantly increase the total amount of manganese release.

In the natural environment of alternation of dry and wet, long rainfall duration is more conducive to the dissolution and release of manganese, especially in the early rainfall of waste rock. Xiangtan is a rainy and long-term city in Hunan Province, which increases the probability of manganese pollution, so it is necessary to pay more attention to the protection of mining environment.

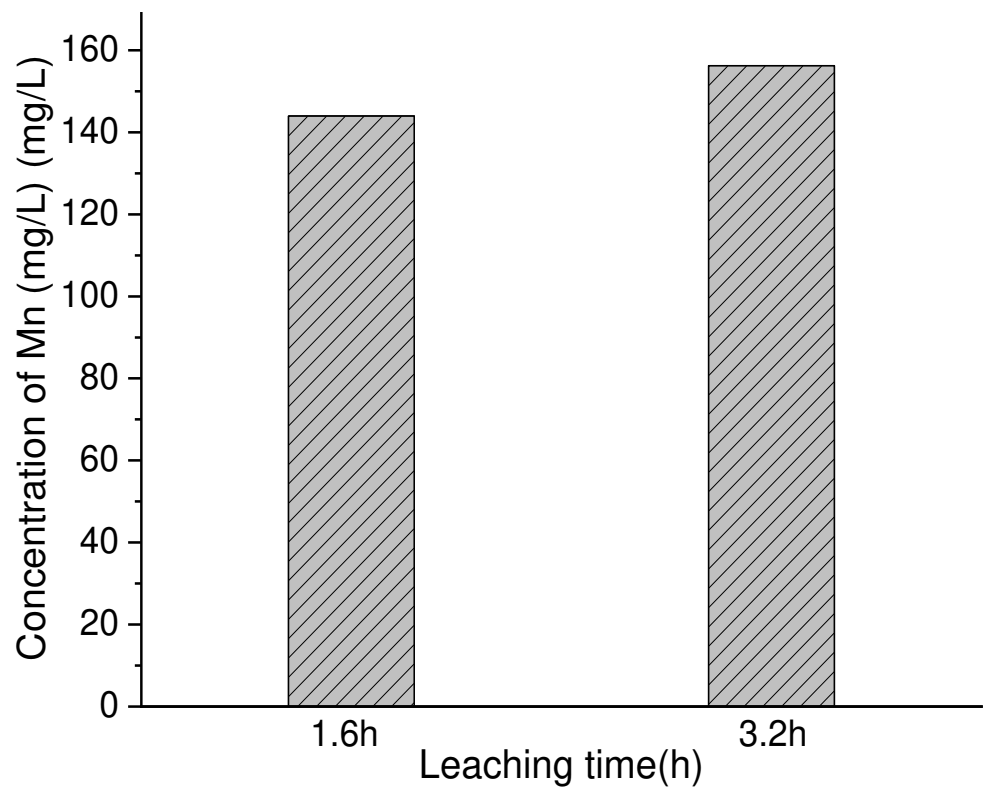

Fig. 10 cumulative release value of manganese in different rainfall

Table 1 Precipitation of $\mathrm{Mn}$ in manganese ore waste during different rainfall periods

\begin{tabular}{|c|c|c|c|c|c|c|c|c|c|c|c|c|c|}
\hline \multirow{2}{*}{$\begin{array}{l}\text { Leaching time } \\
\text { (h) }\end{array}$} & \multicolumn{13}{|c|}{ Precipitation amount $(\mathrm{mg} / \mathrm{kg})$} \\
\hline & 1 & 2 & 3 & 4 & 5 & 6 & 7 & 8 & 9 & 10 & 11 & 12 & accumulate \\
\hline 1.6 & 45.68 & 16.85 & 15.85 & 12.45 & 10.41 & 9.18 & 6.51 & 5.95 & 5.66 & 3.99 & 3.70 & 7.73 & 143.96 \\
\hline 3.2 & 71.95 & 27.25 & 11.58 & 9.95 & 8.27 & 8.13 & 4.65 & 4.60 & 3.57 & 2.41 & 1.98 & 1.89 & 156.23 \\
\hline
\end{tabular}

\subsection{Study on release kinetics of manganese under rainfall leaching}

Through the above experimental methods, ignoring the role of microorganisms, the rainfall 
(1)Physical reaction: At the beginning of the rainfall process, the waste slag exposed on the ground is covered with a large amount of adsorbed soluble minerals and soluble salts. The initial moment of leaching, it is hit by rain water, and under the action of shear force, it is quickly washed away into the leachate, and the manganese concentration of leachate increases rapidly.

(2) Chemical reaction: with the continuation of the rainfall process, the soluble minerals adsorbed on the surface are exhausted. Then the ore surface inside the waste begins to contact with the rain water. Under the action of rain water and air, the surface oxidizes and releases manganese. At the same time, when the surface oxidation is carried out, the alkali ions in the waste will be replaced, resulting in alkaline leachate. In the meanwhile, a variety of micro galvanic reactions will be formed, a large amount of manganese metal will be precipitated, and the manganese concentration in the leachate will increase to the maximum value.

The release mechanism of manganese from manganese ore waste (particle size $>80$ mesh, solid-liquid ratio 1:20) in the process of rainfall leaching was simulated by using the release kinetic model of double constant and elovich equation. It is shown from Fig. 11 and Table 2 that both the double constant and elovich equation can describe the release mechanism of manganese ore waste rock under rainfall leaching, and the fitting results of double constant equation model are better than that of elovich equation.

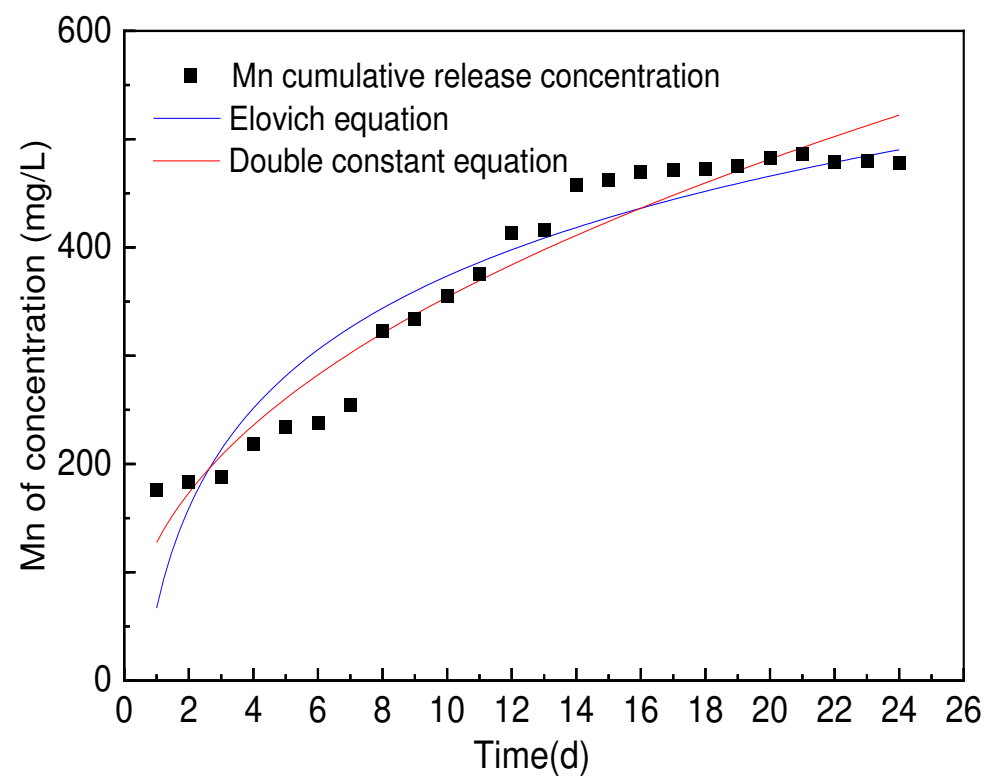

Fig.11 fitting of cumulative release of $\mathrm{Mn}$ in waste rock Table 2 fitting table of equation results

\begin{tabular}{llccc}
\hline \multirow{2}{*}{ Kinetic equation } & \multirow{2}{*}{ Equation expression } & \multicolumn{3}{c}{ Coefficients } \\
\cline { 3 - 5 } & & $\mathrm{a}$ & $\mathrm{b}$ & $\mathrm{R}^{2}$ \\
\hline
\end{tabular}




$\begin{array}{lcccc}\begin{array}{l}\text { Double constant } \\ \text { equation }\end{array} & \ln q=\ln a+b \ln t & 127.48136 & 0.44369 & 0.9287 \\ \text { Elovich equation } & \mathrm{q}=\mathrm{a}+b \ln t & 66.837 & 133.20725 & 0.86978\end{array}$

366

\section{Conclusion}

The results of static toxicological leaching experiment show that: The disturbance state will increase the concentration gradient of manganese in the leaching solution, promote the release of manganese; the leaching trend of waste rock in different solid-liquid ratio is basically consistent, the higher the solid-liquid ratio, the higher the precipitation concentration, the maximum release of manganese when the solid-liquid ratio is 1:5; the smaller the particle size, the more conducive to the dissolution and release of manganese When the particle size of waste rock is more than 80 mesh (less than $180 \mu \mathrm{m}$ ), the precipitation of manganese is the largest.

The results showed that the effect of rainfall intensity on Mn was small, which was mainly reflected in the low rainfall intensity $(80$ Under different rainfall $\mathrm{pH}$ conditions, alkaline conditions are conducive to $\mathrm{Mn}$ release; in the natural environment of alternation of dry and wet, long rainfall duration is more conducive to Mn release, especially in the early rainfall leaching process of fresh waste rock, and the increase of rainfall duration contributes to the increase of Total Mn release.

The simulation results of heavy metal release kinetics model showed that the leaching process included physical reaction and chemical reaction. The double constant equation model and elovich equation model are introduced to describe the leaching and release kinetics of manganese ore waste rock. The fitting results show that the double constant equation model can better describe the release process of manganese ore waste rock.

\section{Declarations}

Ethical approval and consent to participate Not applicable.

Consent for publication Not applicable.

Competing interests The authors declare that they have no competing interests.

Authors Contributions B R and X W contributed to the study design. Measurement 

the work. Y Z and Y S commented on previous versions of the manuscript and provided valuable reviews. All authors read and approved the final manuscript.

Funding information This work was supported by the National Natural Science Foundation of China (No. 41973078), and Natural Science Foundation of Hunan Province (No.2019JJ40081)

Data availability All data generated or analyzed during this study are included in this published article.

399

400

401

402

\section{References}

Bozhi, R., Qian, W., Yangbo, C., Wenjie, D., Xie, Z., Jesus, S. "Analysis of the Metals in Soil-Water Interface in a Manganese Mine", J ANAL METHODS CHEM, (2015).

Bozhi, R., Xie, Z., Binquan, L, Yi, Z. "Research on heavy metal content correlation analysis and principal component analysis of contaminated flow from soil-water interfaces in manganese ore zone", Environmental Engineering, 32(07), 54-58(2014).(China)

Bozhi, R., Yingying, Z., Andrew, S.H., Renjian, D., Miguel, D.L.G. "Research on the Characteristics and Mechanism of the Cumulative Release of Antimony from an Antimony Smelting Slag Stacking Area under Rainfall Leaching", J ANAL METHODS CHEM, (2017).

Bing, L., Qin, D., Liguo, J. "Effects of Acid Rain to the Internal Acidities of Phosphate Waste Rock Pile and Coal Gangue", Bulletin of Mineralogy,Petrology ang Geochemistry, 35(01), 188-192(2016).(China)

Emilia, F.O., Gianluigi, B., Antonio, M.L., Francisco, B.N., Irene, O., M., N.J. "Use of BCR sequential extraction procedures for soils and plant metal transfer predictions in contaminated mine tailings in Sardinia", J GEOCHEM EXPLOR, 172(2017).

Hai, L., Mingli, Y., Yingbo, D., Quanli,L., Shuyue, L., Yue, L. "The heavy mental leaching rules and influence mechanism of different particle size of tin mining waste rock", China Environmental Science, 34(03), 664-671(2014).(China)

Herndon, E.M., Havig, J.R., Singer, D.M., Mccormick, M.L., Kump, L.R. "Manganese and iron geochemistry in sediments underlying the redox-stratified Fayetteville Green Lake", GEOCHIM COSMOCHIM AC, 231, 50-63(2018).

Jianbing, W., Zhipeng, C, Mingxing, D, Qin, D, Yanxia, W. "Leaching characteristics and release law of heavy metals from the mining mullock and tailings in nonferrous metal mining industry", Ecology and Environmental Sciences, 23(02), 300-306(2014).(China)

Kukurugya, F., Kim, E., Nielsen, P., Horckmans, L., Spooren, J., Broos, K., Quaghebeur, M. "Effect of milling on metal leaching: Induction of galvanic effect in a secondary lead smelter matte by prolonged milling", HYDROMETALLURGY, 171, 245-253(2017).

Li, Y., Yang, X., Geng, B., Liu, X. "Effective bioremediation of $\mathrm{Cu}(\mathrm{II})$ contaminated waters with immobilized sulfate-reducing bacteria-microalgae beads in a continuous treatment system and mechanism analysis", Journal of chemical technology and biotechnology (1986), 93(5), 1453-1461(2018). 
Li, Y., Yangsheng, L. "The leaching principles of heavy metals in lead and zinc tailings in simulation acid rain", Environmental Engineering, 30(S2), 586-590(2012).(China)

Ning, P., Qinglin, P., Hui, L., Zhihui, Y., Gongliang, W. "Recovery of iron and manganese from iron-bearing manganese residues by multi-step roasting and magnetic separation", MINER ENG, 126(2018).

Ning, L., Bozhi , R., Yingying, Z., Yao, Z. "Study on Pollution and Remediation of Heavy Metals in Soil", Guangzhou Chemical Industry, 45(09), 30-32(2017).(China)

Qingqing, Z., Aijiang, Y., Wei, Y., Shan, L. "Leaching of Heavy Metal in Antimony Mine Tailings by Sulfur-oxidizing Bacteria", Environmental Science \& Technology, 37(05), 26-30(2014).(China)

Saijun, Z., Andrew, H. "The Impact of Physical Properties on the Leaching of Potentially Toxic Elements from Antimony Ore Processing Wastes", INT J ENV RES PUB HE, 16(13),(2019).

Siyu, Z., Xuwen, H., Yan, L., Zengqiang, F., Hao, W. "Leaching experimental study on heavy metals in soil lead-zinc mine", Journal of Mining Science and Technology. Journal of Mining Science and Technology", (4), 406-416(2018).(China)

Sun, Z., Xie, X., Wang, P., Hu, Y., Cheng, H. "Heavy metal pollution caused by small-scale metal ore mining activities: A case study from a polymetallic mine in South China", SCI TOTAL ENVIRON, 639, 217-227(2018).

Xuejun, G., Kunpeng, W., Mengchang, H., Ziwei, L., Hailin, Y., Sisi, L. "Antimony smelting process generating solid wastes and dust:Characterization and leaching behaviors", J ENVIRON SCI-CHINA, 26(07), 1549-1556(2014).

Xingyun, H., Mengchang, H., Sisi, L., Xuejun, G. "The leaching characteristics and changes in the leached layer of antimony-bearing ores from China", J GEOCHEM EXPLOR, (2016).

Yingying, Z., Bozhi, R., Ning, L., Yao, Z. "Study on Cause and Control of Heavy Metal Pollution in Manganese Area", Guangzhou Chemical Industry, 45(14), 139-141(2017).(China)

Zhang, Y., Ren, B., Hursthouse, A., Deng, R., Hou, B. "Study on the Migration Rules of Sb in Antimony Ore Soil Based on HYDRUS-1D", POL J ENVIRON STUD, 28(2), 965-972(2018).

Zhou, Y., Ren, B., Hursthouse, A.S., Zhou, S. "Environmental Research; Study Results from B.Z. Ren and Colleagues Update Understanding of Environmental Research (Antimony Ore Tailings: Heavy Metals, Chemical Speciation, and Leaching Characteristics)", Ecology Environment \& Conservation, (2019).

Zhou, S., Li, N., Ren, B., Zhang, P. "Release Law of Sb, As, and Hg in Antimony Smelting Slag Under Simulated Acid Rain", POL J ENVIRON STUD, 26(2), 925-933(2017).

Zhangxiong, H., Dejun, W., Jianping, H., Long, L., Qiang, L. "Tiangyang, N. Migration and Transformation of Heavy Metals in Soil and Its Influencing Factors", Multipurose Utilization of Mineral Resources, (6), 5-9(2017).(China)

Zhang, Y., Ren, B., Hursthouse, A., Deng, R., Hou, B. "Leaching and Releasing Characteristics and Regularities of Sb and As from Antimony Mining Waste Rocks", POL J ENVIRON STUD, 28(5), 4017-4025(2019). 
Figures

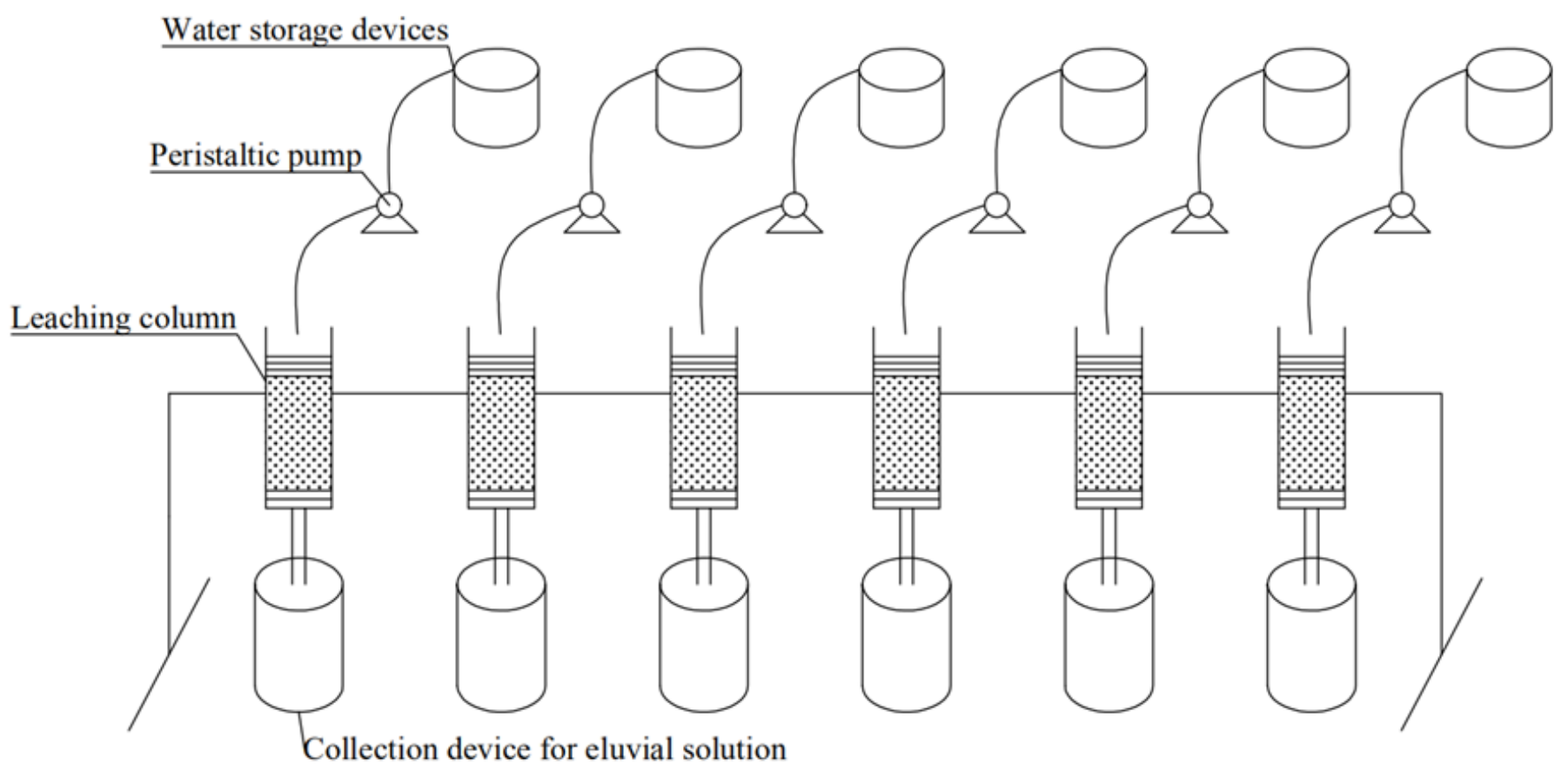

Figure 1

dynamic leaching experimental device 


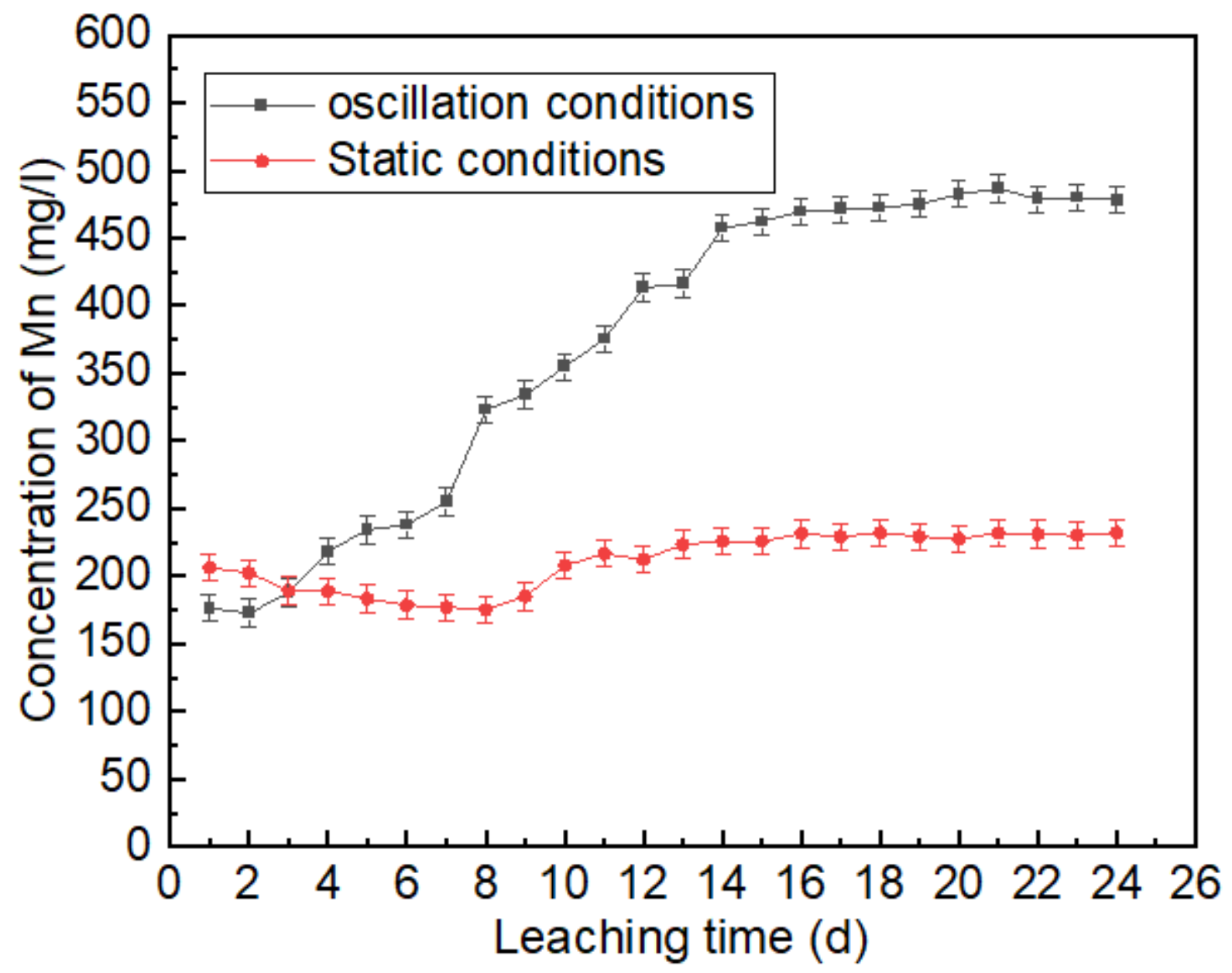

Figure 2

Effect of disturbance ratio on $\mathrm{Mn}$ leaching concentration 


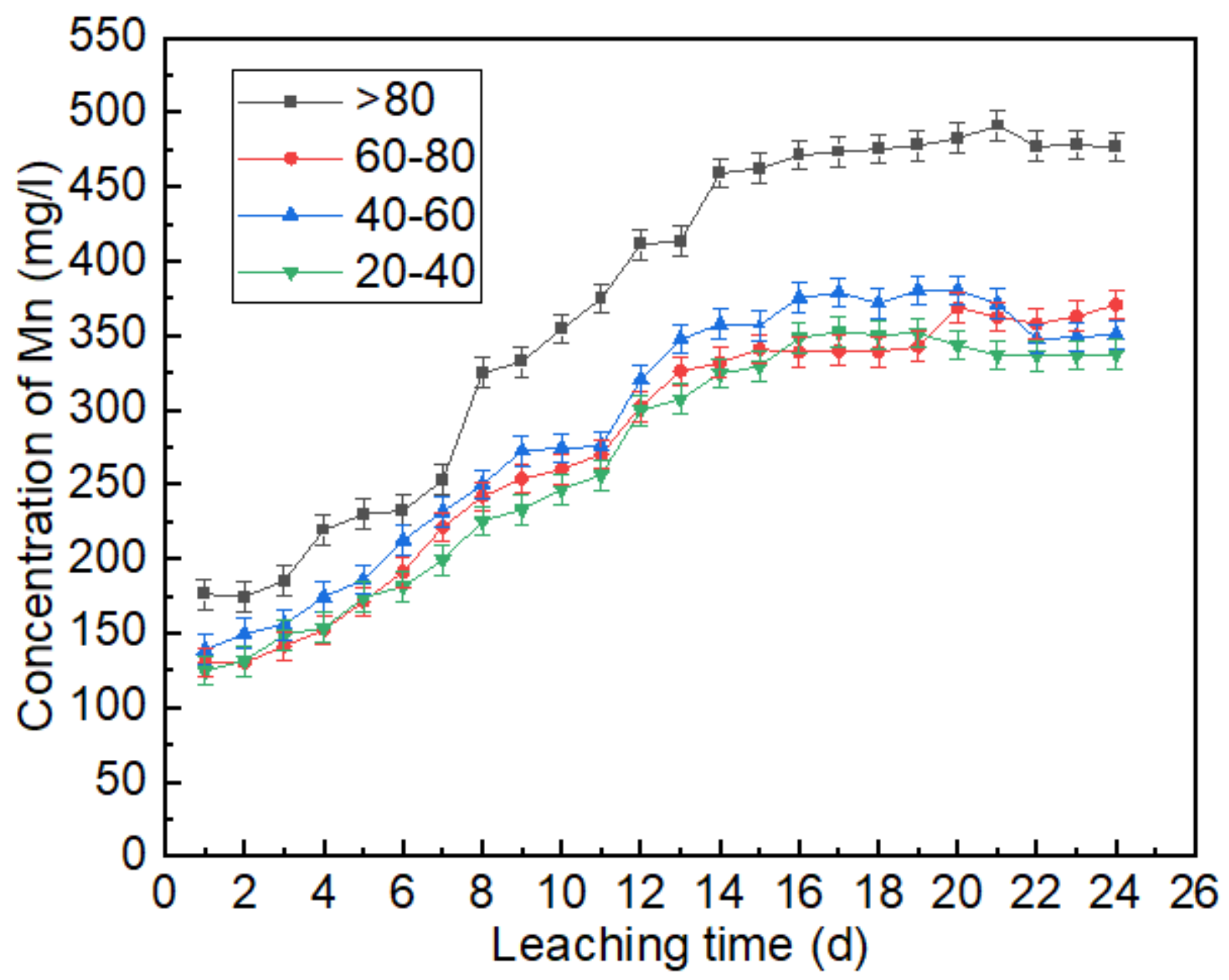

Figure 3

Effect of particle size on $\mathrm{Mn}$ leaching concentration 


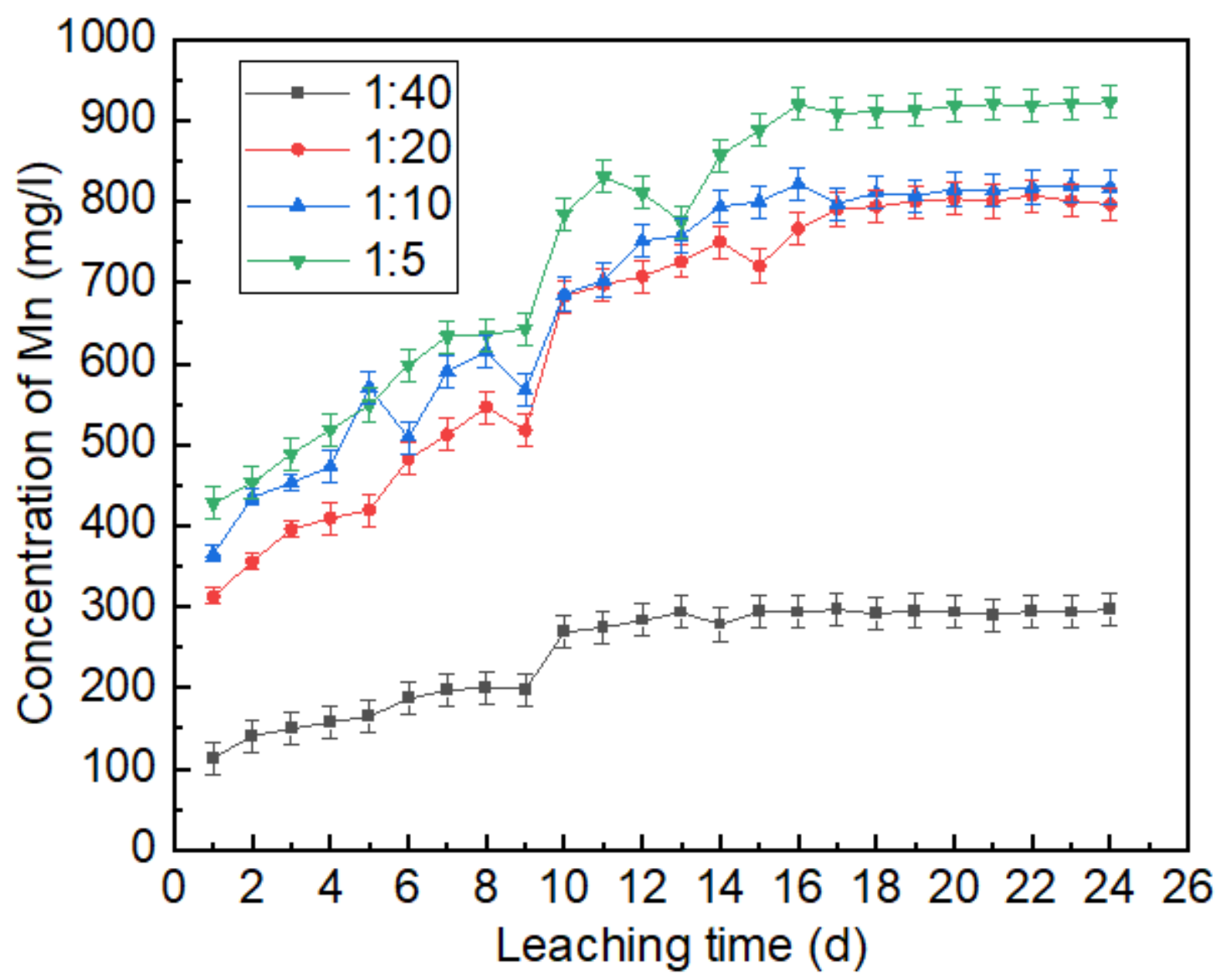

Figure 4

Effect of solid-liquid ratio on Mn leaching concentration 


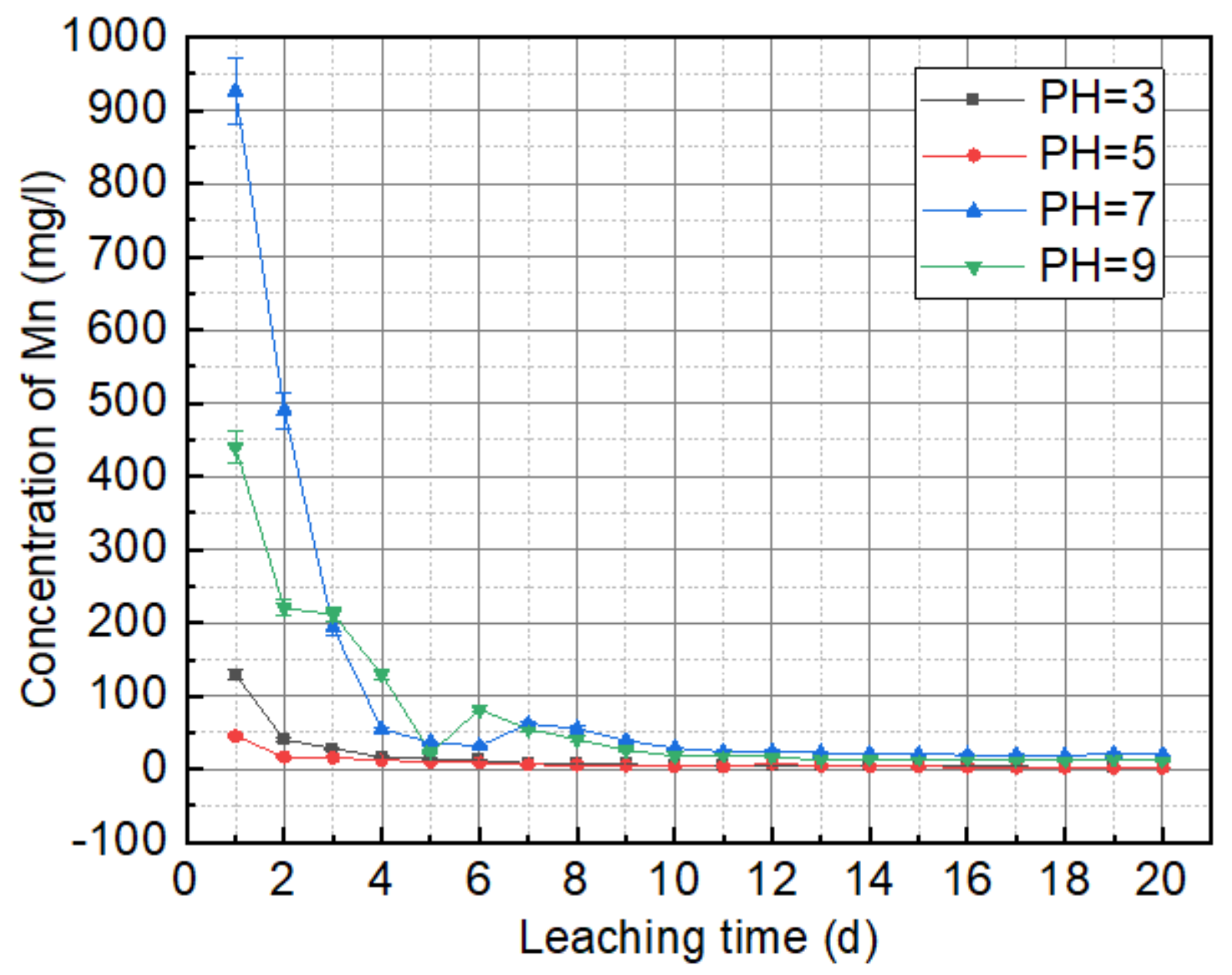

Figure 5

Mn precipitation under different rainfall intensities
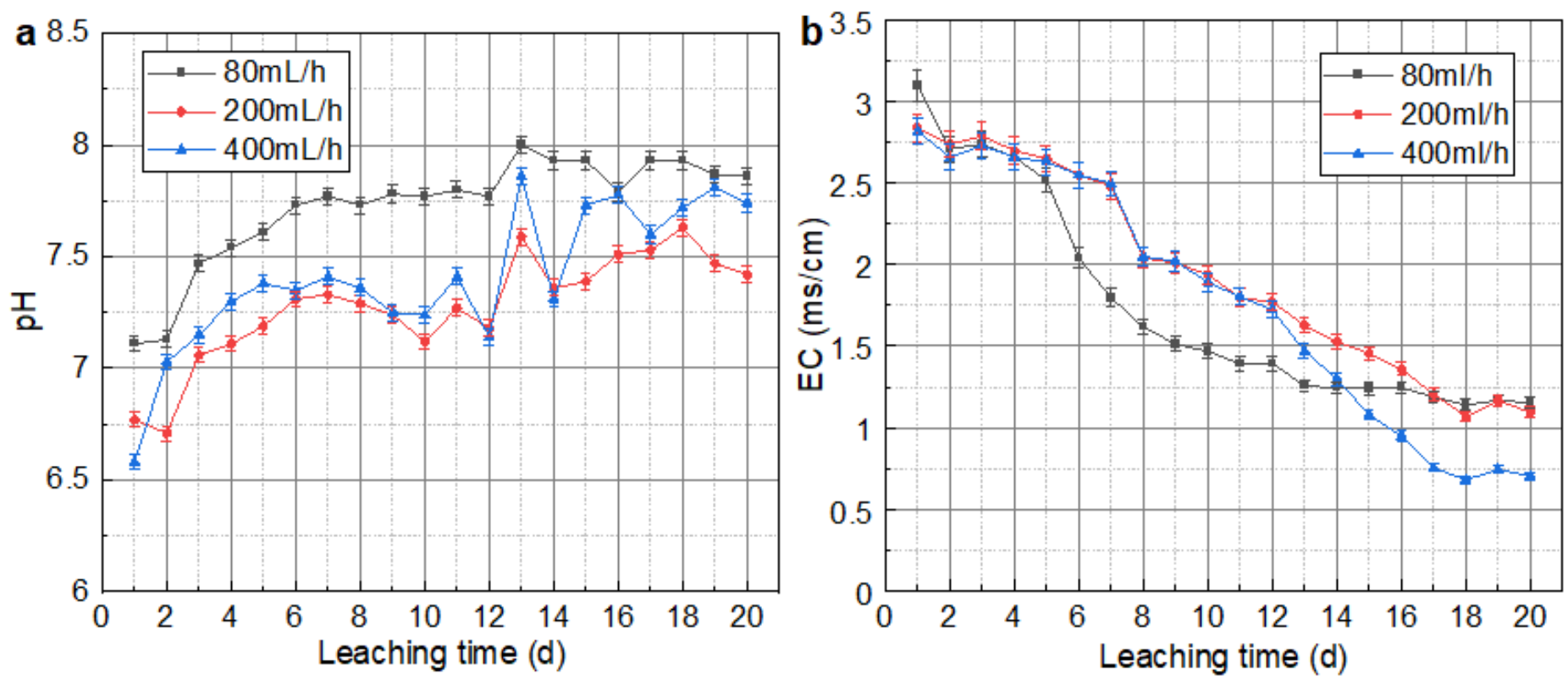
Figure 6

Effects of different rainfall intensities: a) pH value of leachate; b) EC Value of leachate

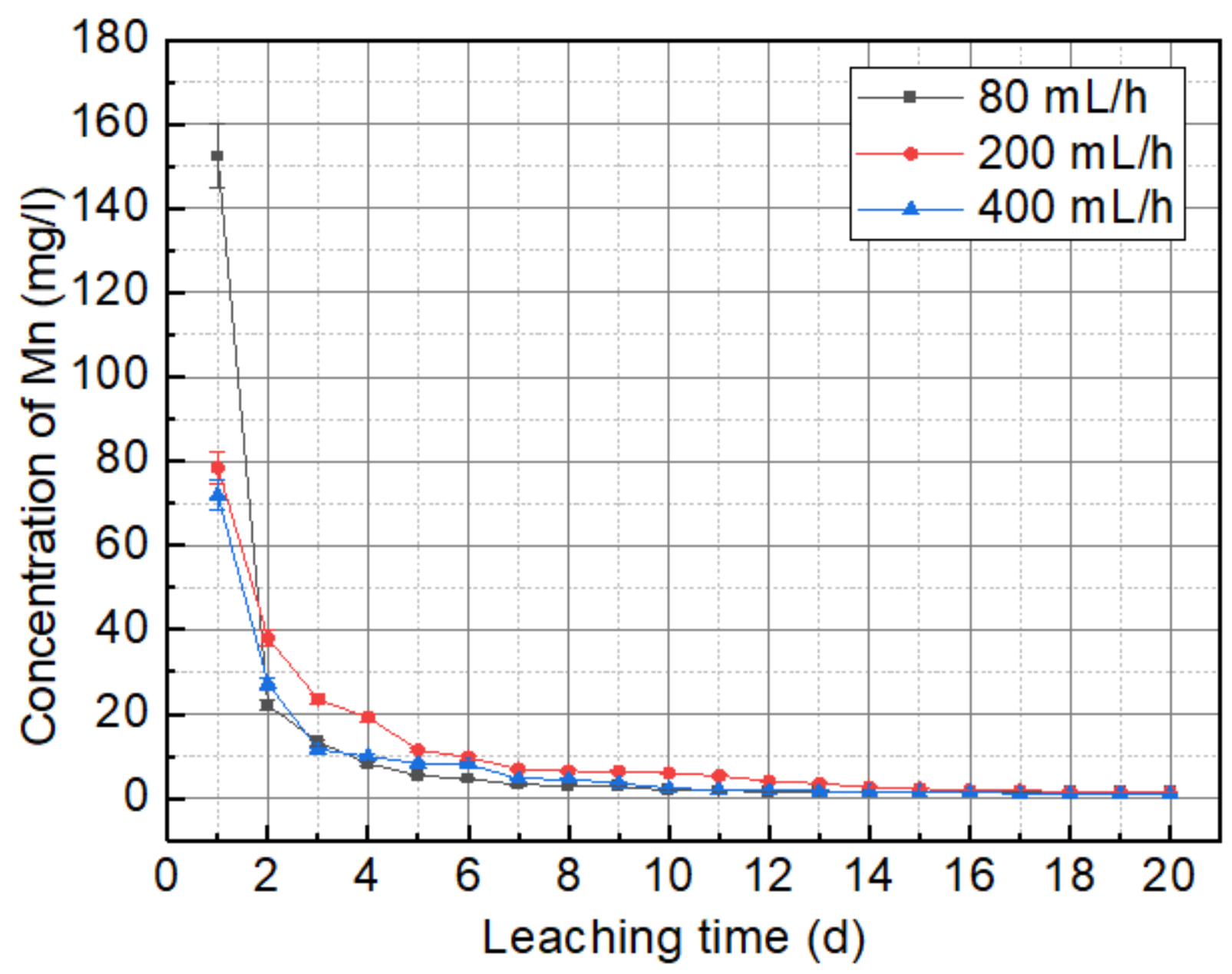

Figure 7

precipitation of $\mathrm{Mn}$ under different rainfall $\mathrm{pH}$ 

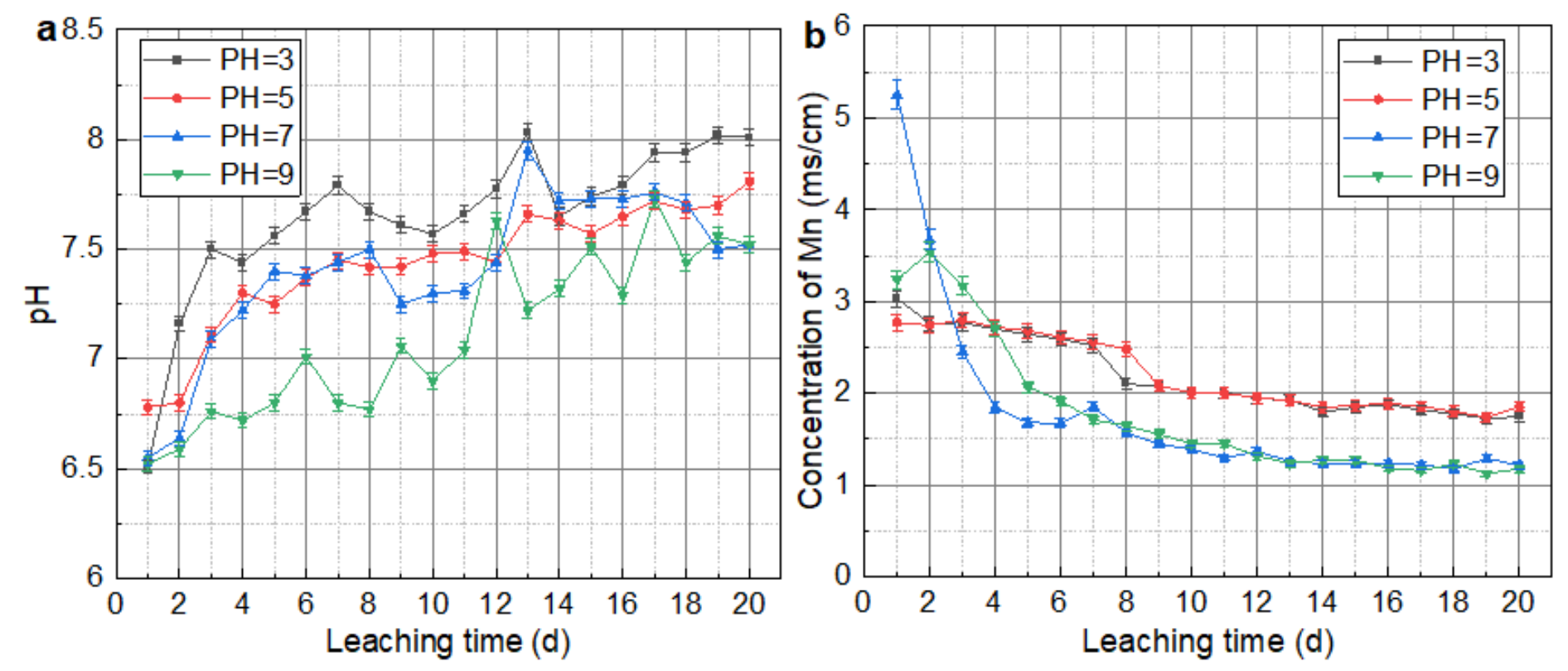

Figure 8

Effect of different rainfall $\mathrm{pH}$ values: a) $\mathrm{pH}$ value of leachate; b) EC Value of leachate
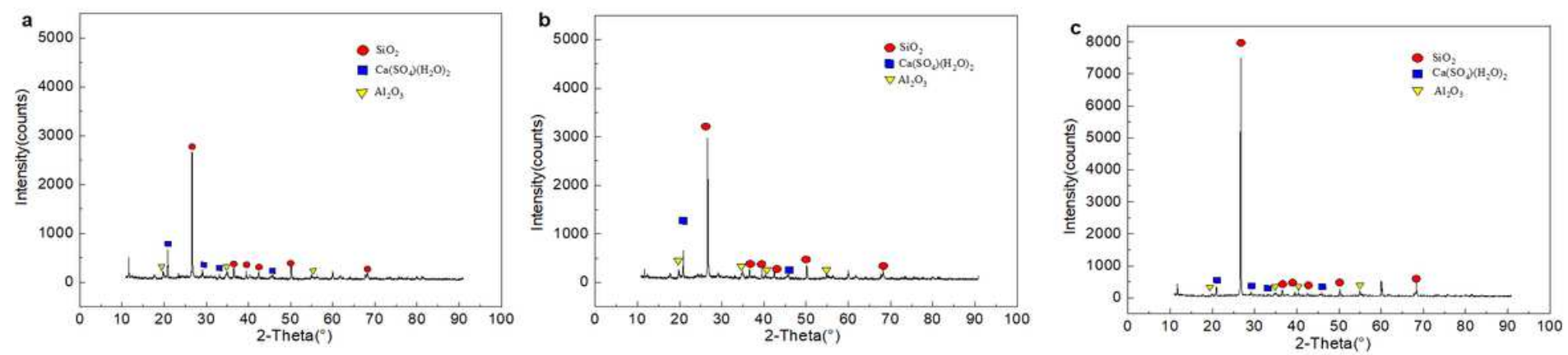

Figure 9

-ray diffraction pattern of manganese ore waste after leaching experiment: a) $\mathrm{pH}=3, \mathrm{~b}) \mathrm{pH}=5.0, \mathrm{c}) \mathrm{pH}=$ 9.0 


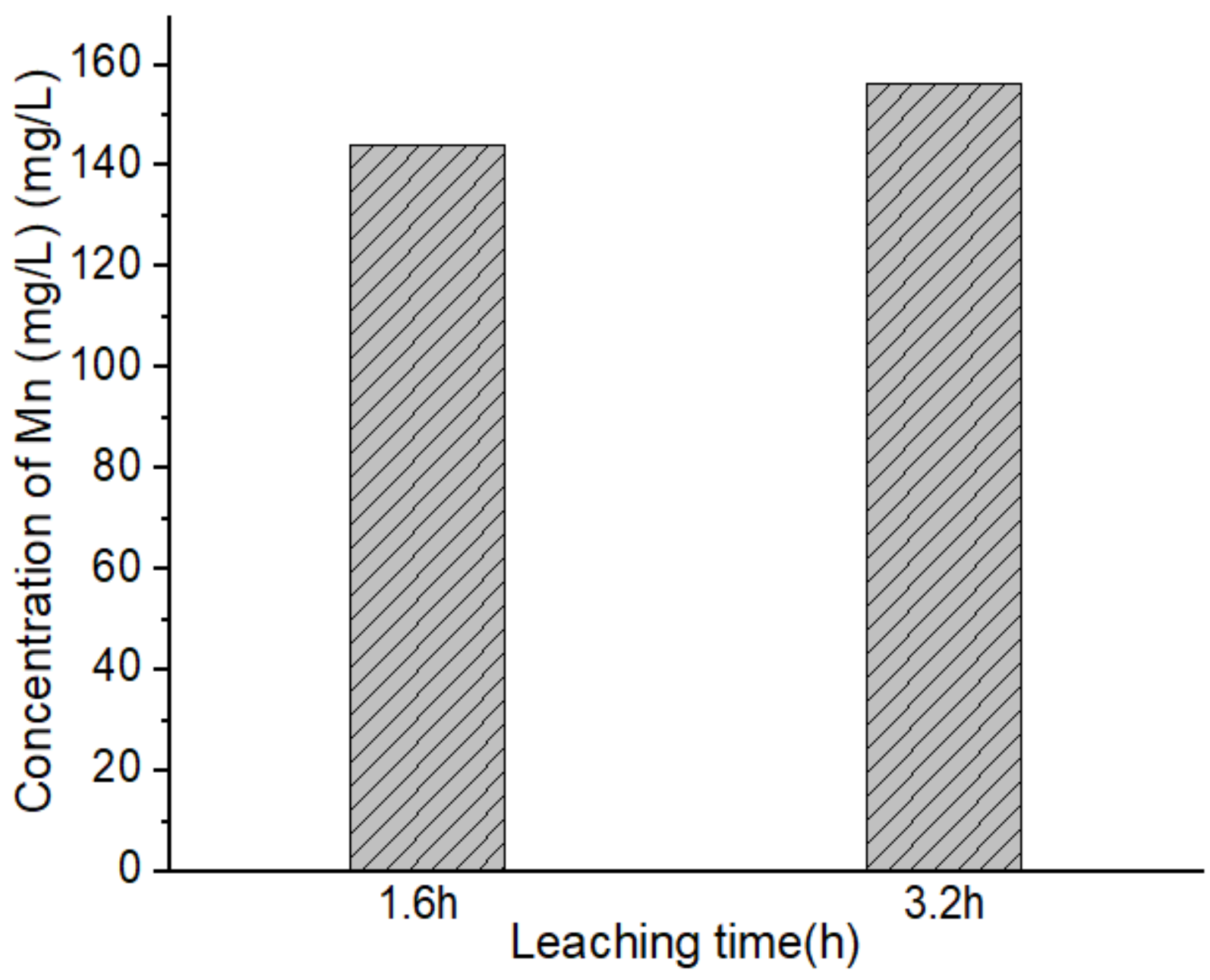

Figure 10

cumulative release value of manganese in different rainfall 


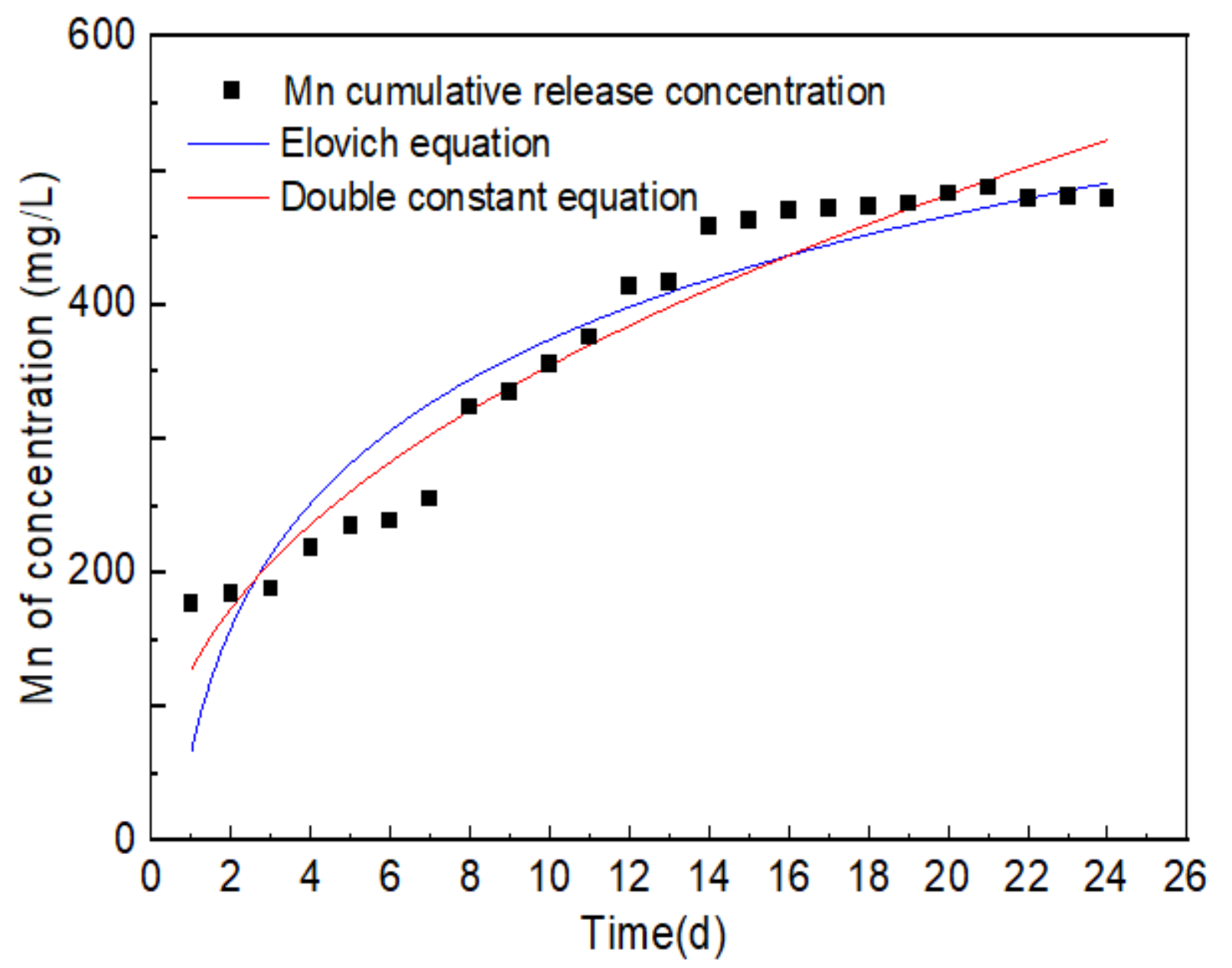

Figure 11

fitting of cumulative release of $\mathrm{Mn}$ in waste rock 